This is an electronic reprint of the original article. This reprint may differ from the original in pagination and typographic detail.

Author(s): Nieminen, Mika

Title: $\quad$ Trade imbalances within the euro area and with respect to the rest of the world

Year: $\quad 2015$

Version:

Please cite the original version:

Nieminen, M. (2015). Trade imbalances within the euro area and with respect to the rest of the world. Economic Modelling, 48, 306-314.

https://doi.org/10.1016/j.econmod.2014.10.012

All material supplied via JYX is protected by copyright and other intellectual property rights, and duplication or sale of all or part of any of the repository collections is not permitted, except that material may be duplicated by you for your research use or educational purposes in electronic or print form. You must obtain permission for any other use. Electronic or print copies may not be offered, whether for sale or otherwise to anyone who is not an authorised user. 


\title{
TRADE IMBALANCES WITHIN THE EURO AREA AND WITH RESPECT TO THE REST OF THE WORLD
}

\author{
Mika Nieminen* \\ Jyväskylä University School of Business and Economics, P.O. Box 35, FI-40014 \\ University of Jyväskylä, Finland
}

\begin{abstract}
Many studies have explored the determinants of current account balances in Europe. However, only in a few studies trade balance has been decomposed into intra balance, trade balance vis-à-vis the euro area, and extra balance, trade balance vis-à-vis the rest of the world. This decomposition is necessary for us to understand why some core euro area countries are acting as financial intermediaries for the periphery countries. Furthermore, the determinants of intra and extra balances might be different because nominal exchange rate cannot adjust between the EMU countries while their financial markets are highly integrated. Thus, we apply this decomposition and supplement the previous studies by including a larger set of theoretically plausible explanatory variables, which is derived from the current account literature. Our contribution is twofold: We observe that, contrary to Schmitz and von Hagen (2011), the introduction of common currency has not increased the elasticity of net capital flows to per capita incomes within the euro area for the member countries. On the other hand, there is a great heterogeneity among the usual determinants of trade balances whether those contribute to intra balances or extra balances. These results increase our understanding of the imbalances in the euro area.
\end{abstract}

Keywords: Current account, Trade balance vis-à-vis the euro area, Trade balance vis-à-vis the rest of the world, European monetary union, Culture, Institutions

JEL classification: F21, F32, F33, F36, Z10

\footnotetext{
* E-mail address: mika.p.nieminen@jyu.fi, Tel.: +358504016350
} 


\section{Introduction}

Despite the fact that the euro area as a whole has been in balance with the rest of the world, many euro area member countries have had substantial current account imbalances. These imbalances had a tendency to grow after the adoption of the common currency in 1999. However, in order to fully understand these imbalances we need to look at how these imbalances have been distributed between balances against the euro area and balances against the rest of the world (see, e.g., Eichengreen (2010)). Thus, we follow the decomposition made in Schmitz and von Hagen (2011) and decompose trade balances into intra balances and extra balances. Intra balance measures the trade balance vis-à-vis the euro area, whereas extra balance measures the trade balance vis-à-vis the rest of the world. In some cases, a country has had a positive intra balance but a negative extra balance, or vice versa (see Fig. 1-2). The Netherlands and Belgium-Luxembourg act as financial intermediaries since there is a net capital flow from the rest of the world to these countries and a net capital flow from these countries to the other EMU countries. One aim of this paper is to understand these patterns.

Our analyzing framework provides interesting insights. In particular, we can detect whether the determinants are different between intra and extra balances. This might help us to understand why some countries have positive intra balances but yet negative extra balances, or vice versa. Using data on the EU-15 countries from 1984 to 2011, we are able to see whether the relative importance of some variables changed for the euro area member countries after they adopted the euro.

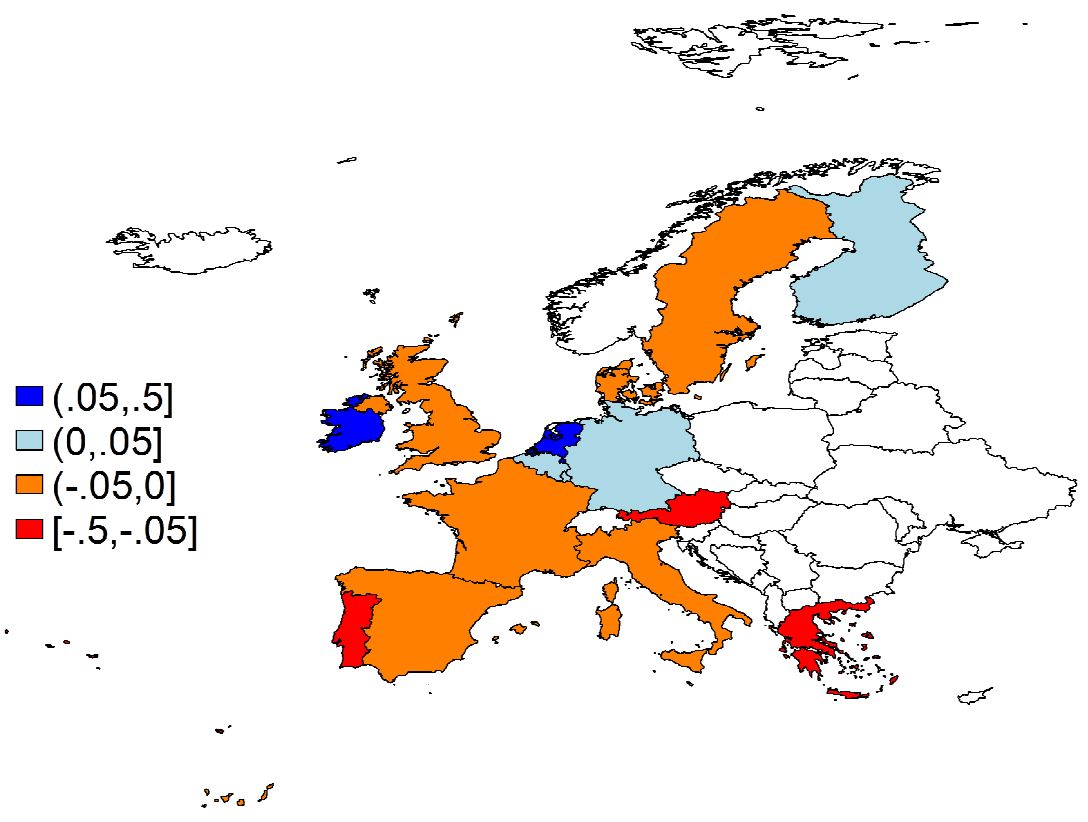

Fig. 1. Intra balances for the EU-15 countries (ratio to GDP) during the period of 1999-2011. 


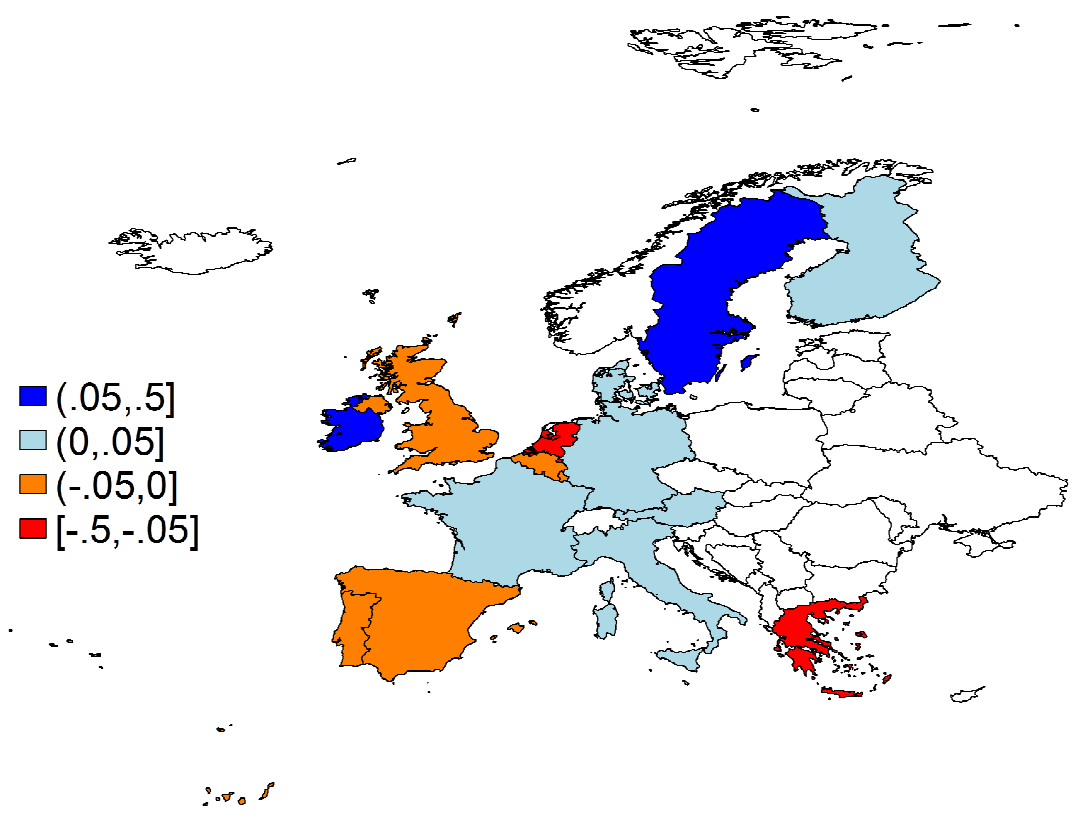

Fig. 2. Extra balances for the EU-15 countries (ratio to GDP) during the period of 1999-2011.

Schmitz and von Hagen $(2011,1676)$ found that "with the introduction of the common currency the elasticity with respect to per-capita incomes of net capital flows within the euro area has increased for the members of the euro zone." However, they included only government budget balances and oil prices as additional explanatory variables. Our paper provides some evidence that if we include a set of explanatory variables that has become standard in the current account literature, this result largely disappears.

Our set of explanatory variables is derived from the current account literature. Therefore, in Section 2 we summarize this literature. In Section 3, we describe our data more closely and explain the reasons we choose to use the Prais-Winsten estimation with panel corrected standard errors. We present our results in Section 4. Section 5 concludes the paper.

\section{Current account imbalances in the euro area}

\subsection{Empirical literature on current accounts}

Chinn and Prasad (2003) explored the medium-term determinants of current account balances using data on 18 industrial and 71 developing countries over the period of 1971-1995. The following set of economic fundamentals turned out to be statistically significant: government budget balances, relative income, dependency ratios, terms of trade volatility, financial deepening, and net foreign assets. Chinn and Ito (2007) and Gruber and Kamin (2007) included institutional variables to account for heterogeneity in the domestic financial markets and the quality of government institutions because investors are more willing to invest in countries that are highly developed in these respects.

There is a strand of literature that follows Chinn and Prasad (2003) in methodology but tries to uncover the special features of the euro area with respect to current 
account dynamics. Slavov (2009) used data on 39 different episodes of common currency agreements between 1976 and 2005. He found that common currency participants had larger current account imbalances. ${ }^{1}$ Further, in a monetary union, the current accounts of the member countries become more sensitive to the economic fundamentals, including relative income. (Slavov 2009.) According to Jaumotte and Sodsriwiboon (2010), the Southern euro area countries have had current account deficits far beyond what can be explained by the IMF's macroeconomic balance (MB) approach or external sustainability (ES) approach (see also International Monetary Fund (2006)). Barnes et al. (2010) came very close by pointing out that the predictive power of standard models to explain the imbalances in the euro area has become weaker (see also Ca' Zorzi et al. (2012)).

\subsection{A catching-up process or diverging competitiveness?}

Two alternative explanations for the widening current account imbalances in the euro area are often emphasized: the ongoing catching-up process between rich Northern Europe and poor Southern Europe or the diverging competitiveness between the two. In the first case widening imbalances are expected to be only temporary, while in the latter those might have undesirable consequences.

By using a simple intertemporal model, Blanchard and Giavazzi (2002) show that for a converging country the recommended level of current account deficit increases with the expected output growth (relative to others) and with the elasticity of substitution between domestic and foreign goods and decreases with the wedge between the domestic interest rate and foreign interest rate. The single European market, goods market integration, has increased the elasticity of substitution, and the monetary union has decreased the wedge within the euro area. In addition, as financial integration reduces the costs to finance investments, investments and the expected future output will increase. Hence, it has become optimal for the poorer countries to run larger deficits. They provide evidence that for the euro area, the relation between the current account balance and income per capita was much stronger during the 1994-2000 period than during the 1985-1993 period. (Blanchard and Giavazzi 2002.)

Schmitz and von Hagen (2011) empirically test whether, among the EU-15 countries, the net capital flows follow differences in per capita incomes. They distinguish between trade balances against euro area and the rest of the world. Their main finding is that the net capital flows follow differences in per capita incomes and that, as a result of introduction of the euro, this elasticity increased but only concerning the net capital flows, which are proxied by the trade flows, inside the euro area. They interpret this as evidence of deepened financial market integration in the euro area and conclude that the widening of current account balances within the euro area should be considered a sign "of the proper functioning of the euro area rather than a sign of improper macroeconomic adjustment". (Schmitz and von Hagen 2011.)

\footnotetext{
${ }^{1}$ Berger and Nitsch (2010) used bilateral trade data on 18 European countries from 1948 to 2008. They observed that, as a result of introduction of the euro, the trade imbalances among the euro area members widened and became more persistent.
} 
Giavazzi and Spaventa (2010) note that in contrast to Blanchard and Giavazzi's (2002) model, foreign borrowing is not necessarily devoted to the production of tradable goods. If a country is borrowing to finance the production of nontradables, it might be unsuccessful in generating the required trade surpluses in the future. (Giavazzi and Spaventa 2010.) Arghyrou and Chortareas (2008) explore the role of real exchange rates in current account determination for the euro member countries. They observe that the real exchange rate enters the cointegrating vector with a nonzero coefficient for most of the countries. (Arghyrou and Chortareas 2008.) By using data for the 11 euro countries from 1982 to 2011 and applying the pooled mean group estimator, Belke and Dreger (2013) attempt to examine the relative importance of catching up and competitiveness for the current accounts. Both of these components are statistically significant with correct signs, but a one percent decrease in competitiveness relative to the euro area average has a larger deteriorating effect on the current account balance than a one percent increase in real per capita income relative to the average. (Belke and Dreger 2013.)

Schnabl and Freitag (2012) remind us that a large number of developing countries have pegged their currencies more or less to the US dollar. By contrast, a large number of European countries have pegged their currencies to the euro. Schnabl and Freitag use the concepts of a dollar bloc and euro bloc, which they define in the following way: In the dollar bloc, the U.S. serves as the center country, and East Asia, the Middle East, Latin America, and the Commonwealth of the Independent States are considered the periphery. In the euro bloc, Germany is the center country, and the emerging Europe and industrialized Europe are considered the periphery. They detect an interesting distinction between the two blocks. In the euro bloc, capital flows from the rich center country, Germany, to the poorer periphery. This difference might be explained by the fact that the dollar periphery countries have a higher degree of freedom in managing international capital flows and doing non-marketbased interventions than the euro periphery countries. (Schnabl and Freitag 2012.)

Chen et al. (2013) make an important observation by saying that the explanations for euro area current account imbalances highlighted above, namely, the catching-up process and diverging competitiveness, rely on intra-euro area factors. However, the euro area as a whole is an open economy; therefore, trade and financial linkages between the euro area and the rest of the world are also important. They detect the following pattern: Debtor countries, namely, Greece, Ireland, Italy, Portugal, and Spain, experienced real appreciation, but this largely resulted from the strengthening of the euro. ${ }^{2}$ Greece, Portugal and Spain had a trade deficit not only against the Eurozone but also against the rest of the world. The investors outside the euro area primarily invested in core euro area countries such as Germany and France, whereas private capital flows from the core countries financed the deficits of the GIIPS countries. Consequently, they put forth a hypothesis that external shocks might have had an asymmetric impact on the export performance of Germany and the GIIPS countries. They find evidence that there were differences on how the rise of China, higher oil prices, and the integration of Central and Eastern European countries affected the trade performance of the GIIPS countries compared to Germany. (Chen, Milesi-Ferretti, and Tressel 2013.) Sinn and Wollmershäuser (2012) em-

\footnotetext{
${ }^{2}$ Greece, Ireland, Italy, Portugal and Spain are commonly called as GIIPS countries.
} 
phasize the role of Target balances for the deficit countries to sustain their large current account deficits during the euro crisis. At the time of the financial crisis, the direction of private capital flows changed, and deficit countries financed a large part of their current account deficits with the printing press. (Sinn and Wollmershäuser 2012.) Eurosystem liquidity support has made the external adjustment smoother (Cour-Thimann 2013, 23).

\subsection{One currency, two ways of living}

In the economic growth literature, there has been a debate on the relative importance of formal economic institutions and culture (see, e.g., Acemoglu (2009, 122-136), Acemoglu and Robinson (2012, 56-63), Weil (2009, 407-436), Landes (1999, 516), Tabellini (2010), and Greif (1994)). It might also be the case that differences in institutional quality result from differences in culture. Maseland (2013) notes that proving this would be difficult not only because of endogeneity problems but also because it is difficult to isolate one from the other. Maseland himself uses Toxoplasma gondii as an instrumental variable for certain aspects of culture because this infection tends to change an individual's personality. However, its prevalence rate is not related to any aspect of economic development. First, toxoplasma seroprevalence has a strong negative effect on cultural indicator (the first principal component of Hofstede's power distance, individualism, and uncertainty avoidance and World Values Survey's distrust). ${ }^{3}$ Second, culture has a strong positive effect, instrumented by toxoplasma seroprevalence, on institutional quality (the first principal component of the quality of political institutions, governance and rule of law.) (Maseland 2013.)

Gorodnichenko and Roland (2010) build a Schumpeterian growth model with some new flavors: collectivist cultures are more efficient in combining (existing) intermediate inputs, individualist entrepreneurs obtain higher utility from producing intermediate goods of higher than average quality, and the government acts in a predatory way by expropriating the profits from innovations. They are able to prove that the ratio of labor devoted to research increases with the level of individualism, decreases with the strength of the predatory government institutions and is independent of the collectivist culture's competitive edge in the production of final goods. Thus, although collectivism generates static efficiency gains, it has no effect on economic growth, which is largely determined by innovations. Using genetic distance to population in the US as an instrumental variable, Gorodnichenko and Roland also provide empirical evidence that individualistic culture has a strong causal effect on economic development. (Gorodnichenko and Roland 2010.)

Although all of the EU-15 countries can be considered developed economies, large cultural differences exist between the countries. Holinski et al. (2012) claim that fundamental economic factors cannot explain the combination of no convergence in per capita incomes and persistent imbalances within the euro area between the South and North. They call for recognition of cross-country differences in time preference, planning horizon, and risk aversion as a way to proceed. (Holinski, Kool, and Muysken 2012.) De Castro Campos et al. (2013) provide evidence that indicators

\footnotetext{
${ }^{3}$ Power distance, uncertainty avoidance and distrust loaded negatively whereas individualism positively.
} 
of thrift, trust and religiosity from the World Values Survey / European Values Study help to explain cross-country heterogeneity in private saving.

\section{Data and empirical methodology}

Our sample consists of the EU-15 countries, but because Belgium and Luxembourg are aggregated, we actually have 14 countries. ${ }^{4}$ The sample covers the period from 1984 to 2011. Neither the countries that adopted the euro after 2001 nor the countries that joined the EU after 1995 are included into our sample. There are three reasons for this: First, these countries would differ substantially from the EU-15 countries. Second, those countries that adopted the euro after 2001, namely, Slovenia in 2007, Cyprus and Malta in 2008, Slovakia in 2009, and Estonia in 2011, have only a brief experience with the common currency. Third, we want to follow Schmitz and von Hagen (2011) as closely as possible.

The correlation between trade balances (excluding services) and current account balances is strong: 0.59 when Ireland is included and 0.81 when it is excluded. ${ }^{5}$ Hence, the current account literature is a good starting point for finding the main determinants of trade balances as well. ${ }^{6}$ Typically, for the EU-15 countries, intra trade has accounted for approximately half of their trade (see Appendix A, Table 6).

Descriptive statistics for the sample are provided in Table 1 . Domestic credit by banks is a commonly used proxy for the quality of domestic financial markets. Bureaucracy quality from the Political Risk Services' International Country Risk Guide is a good proxy for the quality of government institutions. ${ }^{7}$ We use Hofstede's (2001) dimensions of national culture to measure the potential cultural differences among the EU-15 countries (see detailed information about the individualism index from the Appendix A). ${ }^{8}$ Individualism index is time-invariant, but on the other hand, national cultures change only very slowly. We also include the real interest rate and changes in unit labor costs into our model. We include the real interest rate instead of Taylor rule deviations because it would be very difficult to derive monetary policy reaction functions for the euro member countries from 1984 onwards. All our explanatory variables are derived from the current account literature, which we summarized in Chapter 2.

\footnotetext{
4 Belgium and Luxembourg are aggregated because, before 1997, there are no numbers for these countries separately in the IMS's Direction of Trade Statistics. Consequently, with regard to our dependent variables, Intra balance and Extra balance, and Target balance, we use aggregated numbers for Belgium-Luxembourg. With regard to other explanatory variables, we use values of Belgium because the relative size of Luxembourg is so small. (Between 1984-2011 GDP of Luxembourg was only $7.6 \%$ of the of Belgium.)

5 The numbers for the current account balances were taken from WDI and WEO. For Belgium-

Luxembourg, we used Belgium's numbers.

6 The evolution of our dependent variables, intra balances and extra balances, are presented in Appendix A, Table 5. Neither intra balance nor extra balance includes services.

7 Political Risk Services' International Country Risk Guide was used for example in Chinn and Ito (2007).

${ }^{8}$ Hofstede's dimensions of national culture have been used by several economists (see, e.g., Altug and Canova (2014), Gorodnichenko and Roland (2011), or Maseland (2013)).
} 
Table 1

Descriptive statistics of the sample.

\begin{tabular}{|c|c|c|c|c|c|c|}
\hline Variable & Units & Mean & Min & Max & $\begin{array}{l}\text { St. } \\
\text { dev. }\end{array}$ & $\begin{array}{l}\text { share of } \\
\text { over } \\
\text { time } \\
\text { variance }\end{array}$ \\
\hline Intra balance & ratio to GDP & 0.004 & -0.108 & 0.244 & 0.063 & 0.138 \\
\hline Extra balance & ratio to GDP & -0.004 & -0.171 & 0.124 & 0.043 & 0.289 \\
\hline GDP per capita & in tens of thousands of euros & 2.103 & 0.322 & 4.318 & 0.884 & 0.662 \\
\hline Fiscal balance & ratio to GDP & -0.034 & -0.309 & 0.070 & 0.042 & 0.704 \\
\hline Oil price & euros $/$ barrel $^{*} 0.01$ & 0.291 & 0.114 & 0.807 & 0.185 & 1.000 \\
\hline $\begin{array}{l}\text { Dependency ratio } \\
\text { (aged) }\end{array}$ & & 0.232 & 0.162 & 0.319 & 0.032 & 0.496 \\
\hline $\begin{array}{l}\text { Dependency ratio } \\
\text { (child) }\end{array}$ & & 0.271 & 0.202 & 0.495 & 0.045 & 0.445 \\
\hline $\begin{array}{l}\text { Domestic credit by } \\
\text { banks }\end{array}$ & ratio to GDP & 1.138 & 0.482 & 2.344 & 0.403 & 0.824 \\
\hline Bureaucracy quality & index, scaled from 0 to 4 & 3.640 & 1.750 & 4.000 & 0.551 & 0.215 \\
\hline Real interest rate & $\begin{array}{l}\text { percentages multiplied by } \\
0.01\end{array}$ & 0.029 & -0.051 & 0.123 & 0.028 & 0.966 \\
\hline Change in RULCa & $\begin{array}{l}\text { change in the index value } \\
\text { (2005=100 for all countries) }\end{array}$ & -0.000 & -0.089 & 0.085 & 0.018 & 0.980 \\
\hline $\begin{array}{l}\text { Hofstede's } \\
\text { individualism }\end{array}$ & $\begin{array}{l}\text { Index (original numbers } \\
\text { were multiplied by } 0.01 \text { ) }\end{array}$ & 0.646 & 0.270 & 0.890 & 0.166 & 0.000 \\
\hline $\begin{array}{l}\text { Change in Target } \\
\text { balances }\end{array}$ & ratio to GDP & -0.003 & -0.586 & 0.244 & 0.046 & 0.953 \\
\hline
\end{tabular}

Even though we are using annual data, both the intra balance and extra balance vary more across countries than within countries over time. Therefore, it is not meaningful to use a within estimator. Beck and Katz (1995) provide evidence that the ParksKmenta method, FGLS for panel models accounting for heteroskedasticity, crosscorrelation, and serial correlation of the residuals, is overconfident, for example, when $\mathrm{N}=15$ and $\mathrm{T}=30$. For these reasons, we use the Prais-Winsten estimation with panel-corrected standard errors, which allows residuals to be contemporaneously correlated across panels. This is crucial in our context when we are estimating Intra balances. Within the euro area, the economies are closely linked, and the surplus of one country is always the deficit of another country. In addition to contemporaneous correlation, our standard errors allow for panel-level heterogeneity and a common AR(1) autocorrelation structure. Schmitz and von Hagen (2011) used the PraisWinsten estimator with panel-corrected standard errors. We do not include period dummies in our model because these cannot be identified when we are including Oil price, which is assumed to be the same for all countries. Consequently, our regression model has the following very simple form:

balance $_{i t}=\alpha+x_{i t}^{\prime} \beta+\varepsilon_{i t}$

where balance it is either the intra balance (ratio to GDP) excluding services or the extra balance (ratio to GDP) excluding services for country $i$ in period $t$, $a$ is a con- 
stant (common for all countries), $\mathbf{x}_{\mathrm{it}}$ is a column vector including all explanatory variables for country $i$ in period $t, \boldsymbol{\beta}$ is a column vector including all estimated coefficients (common for all countries) and $\varepsilon_{\mathrm{it}}$ is an error term.

\section{Empirical findings}

In our empirical analysis, we take Schmitz and von Hagen (2011) as a starting point. We augment their model by dependency ratios, variables measuring institutional quality, real interest rate, and variables measuring changes in competitiveness. In the last phase, we add variables measuring the dimensions of national culture developed by Hofstede (2001). We include the following dummy variables: EMU, which equals one if the country has adopted the euro and zero otherwise; DKSEUK, which equals one for Denmark, Sweden, and the UK throughout the sample period; and Non-EMU, which equals one if the country has not adopted the euro after the euro was introduced and zero otherwise. Thus, we allow Sweden, Denmark, and the UK to differ from the EMU member countries even before the introduction of the common currency in some respects that our variables fail to measure. By including an interaction term between the EMU dummy variable and GDP per capita, we can detect if the introduction of the euro somehow changed the sensitivity of net capital flows on differences in per capita incomes. Chen et al. (2013) criticized previous studies for concentrating on intra-euro area factors. In our case, this is what we desire because we are trying to understand trade imbalances within the euro area.

\subsection{Panel regressions}

In model (1), we are able to replicate the main results of Schmitz and von Hagen (2011): GDP per capita contributes positively to intra balances, and the introduction of common currency increased the elasticity of net capital flows to per capita incomes within the euro area for the member countries. ${ }^{9}$ However, if we include dependency ratios in our model, the latter disappears (see model (2)). The aged dependency ratio has a negative effect on intra balances, whereas the child dependency ratio has a positive effect. Neither of these contributes to the extra balances. This result remains robust throughout the different specifications. In model (3), we include variables measuring institutional quality. The private credit ratio (domestic credit by banks) is our proxy for the state of the domestic banking sector. Bureaucracy quality measures the quality of government institutions. Within the euro area, capital tends to flow from the highly developed countries to the less developed countries. To some extent, this results from the differences in the quality of domestic financial markets and government institutions. By contrast, domestic credit by banks contributes negatively to extra balances. In the current account literature, usually both the state of domestic financial markets and the quality of government institutions contribute negatively to current account balances. This finding is very interesting and indicates that in this respect, the euro area differs from the world economy

\footnotetext{
${ }^{9}$ In Appendix A, Table 11, we use the period of 1981-2005 and fixed effect panel estimator in addition to the Prais-Winsten estimator just like in Schmitz and von Hagen (2011), and we are able to replicate their results.
} 
as a whole. Countries with the most sophisticated domestic financial sector such as the Netherlands tend to be financial intermediaries with a positive intra balance and a negative extra balance.

Table 2

Regression results for trade balances and per capita incomes in Europe 1984-2011.

\begin{tabular}{|c|c|c|c|c|c|c|}
\hline \multirow[b]{2}{*}{ Variables: } & \multicolumn{2}{|c|}{$\begin{array}{l}\text { Dependent variable: } \\
\text { Intra balance }\end{array}$} & \multicolumn{4}{|c|}{$\begin{array}{l}\text { Dependent variable: } \\
\text { Extra balance }\end{array}$} \\
\hline & $(1)$ & (2) & (3) & (1) & (2) & (3) \\
\hline \multirow[t]{2}{*}{ EMU } & $-0.072^{* * *}$ & 0.011 & 0.002 & -0.006 & -0.009 & -0.003 \\
\hline & $(0.026)$ & $(0.016)$ & $(0.016)$ & $(0.013)$ & $(0.014)$ & $(0.014)$ \\
\hline \multirow[t]{2}{*}{ DKSEUK } & 0.021 & $0.051^{* * *}$ & $0.036^{* *}$ & $0.032^{* *}$ & $0.030^{* *}$ & 0.023 \\
\hline & $(0.013)$ & $(0.016)$ & $(0.017)$ & $(0.014)$ & $(0.015)$ & $(0.016)$ \\
\hline \multirow[t]{2}{*}{ Non-EMU } & -0.032 & 0.000 & -0.003 & -0.007 & -0.009 & -0.004 \\
\hline & $(0.023)$ & $(0.015)$ & $(0.014)$ & $(0.018)$ & $(0.019)$ & $(0.019)$ \\
\hline \multirow[t]{2}{*}{ GDP per capita } & $0.019 * * *$ & $0.036 * * *$ & $0.030^{* * *}$ & $0.019^{* * *}$ & $0.017^{* * *}$ & $0.020 * * *$ \\
\hline & $(0.007)$ & $(0.007)$ & $(0.007)$ & $(0.005)$ & $(0.006)$ & $(0.006)$ \\
\hline \multirow[t]{2}{*}{ GDP per capita*EMU } & $0.028^{* *}$ & -0.006 & -0.001 & 0.002 & 0.004 & 0.002 \\
\hline & $(0.012)$ & $(0.008)$ & $(0.007)$ & $(0.006)$ & $(0.007)$ & $(0.007)$ \\
\hline \multirow[t]{2}{*}{ GDP per capita*DKSEUK } & $-0.020^{* * *}$ & $-0.032^{* * *}$ & $-0.029^{* * *}$ & -0.008 & -0.007 & -0.005 \\
\hline & $(0.007)$ & $(0.007)$ & $(0.007)$ & $(0.006)$ & $(0.006)$ & $(0.007)$ \\
\hline \multirow[t]{2}{*}{ GDP per capita*Non-EMU } & 0.012 & 0.001 & 0.002 & 0.005 & 0.005 & 0.003 \\
\hline & $(0.009)$ & $(0.006)$ & $(0.006)$ & $(0.007)$ & $(0.007)$ & $(0.007)$ \\
\hline \multirow[t]{2}{*}{ Fiscal balance } & -0.010 & -0.040 & -0.020 & -0.038 & -0.038 & $-0.069 *$ \\
\hline & $(0.057)$ & $(0.042)$ & $(0.043)$ & $(0.039)$ & $(0.040)$ & $(0.041)$ \\
\hline \multirow[t]{2}{*}{ Oil price } & $-0.030^{* *}$ & -0.001 & -0.005 & $-0.051^{* * *}$ & $-0.051^{* * *}$ & $-0.045^{* * *}$ \\
\hline & $(0.012)$ & $(0.009)$ & $(0.009)$ & $(0.009)$ & $(0.010)$ & $(0.010)$ \\
\hline \multirow[t]{2}{*}{ Dependency ratio (aged) } & & $-0.552^{* * *}$ & $-0.509^{* * *}$ & & -0.003 & 0.012 \\
\hline & & $(0.162)$ & $(0.155)$ & & $(0.123)$ & $(0.124)$ \\
\hline \multirow[t]{2}{*}{ Dependency ratio (child) } & & $0.358^{* * *}$ & $0.412^{* * *}$ & & -0.044 & -0.056 \\
\hline & & $(0.135)$ & $(0.123)$ & & $(0.107)$ & $(0.104)$ \\
\hline \multirow[t]{2}{*}{ Domestic credit by banks } & & & $0.018^{* * *}$ & & & $-0.019^{* * *}$ \\
\hline & & & $(0.006)$ & & & $(0.006)$ \\
\hline \multirow[t]{2}{*}{ Bureaucracy quality } & & & $0.017^{* * *}$ & & & 0.005 \\
\hline & & & $(0.004)$ & & & $(0.004)$ \\
\hline $\mathrm{R}^{2}$ & 0.144 & 0.174 & 0.264 & 0.156 & 0.157 & 0.188 \\
\hline Observations & 387 & 387 & 387 & 387 & 387 & 387 \\
\hline
\end{tabular}

In addition, all regressions include a constant. Notes: Estimation was performed using the Prais-Winsten estimator with panel-corrected standard errors (panel-level heteroskedastic and correlated across panels, common $\mathrm{AR}(1)$ autocorrelation structure, which is estimated from the autocorrelation of residuals ( $x$ tpcse command in STATA with correlation(ar1) and rhotype(tscorr) options)). Panel-corrected standard errors are in parenthesis. ${ }^{*},{ }^{* *}$ and ${ }^{* * *}$ denote statistical significance at the 10,5 and 1 percent levels.

In Table 3, we present the models that we prefer. In model (4), we include the real interest rate, and real unit labor costs. We expect a low real interest rate to have a deteriorating effect on trade balances because a low real interest rate can reflect a loose monetary policy. However, in model (4), we observe that real interest rate is not statistically significant. The explanatory power of our model increases dramatically when we include real unit labor costs (compare models (3) and (4)). Real unit labor costs are measured at the total economy level and relative to the rest of the EU15 countries (see Appendix A, Table 7). Real unit labor costs have the expected sign: if a country loses its price competitiveness relative to the EU-15 countries, its intra surplus (deficit) tends to decrease (increase). 
Overall, our model is more capable of explaining intra balances than extra balances, which is understandable because our analysis relies mainly on intra-euro area factors. We write out interpretations for the regression coefficients that, according to model (4), differ statistically significantly from zero: Denmark, Sweden and the UK have, on average, $4 \%$ (of GDP) larger (smaller) intra surpluses (deficits) than the other EU-15 countries. If a country has a GDP per capita that is 10,000 euros larger, our model predicts that its intra surplus (deficit) is 3\% (of GDP) larger (smaller). However, for Denmark, Sweden, and the UK, this effect is smaller, on average, only $1 \%$ (of GDP). If the aged dependency ratio increases by 0.1 , a country tends to have a $6 \%$ (of GDP) smaller (larger) intra surplus (deficit). By contrast, if the child dependency ratio increases by 0.1 , a country tends to have a $4 \%$ (of GDP) larger (smaller) intra surplus (deficit). If a country has a $10 \%$ higher private credit ratio, its extra deficit (surplus) tends to be $0.2 \%$ (of GDP) larger (smaller). For the intra balances, it is just the opposite. This result is interesting and in line with both Schnabl and Freitag's (2012) and Chen et al.'s (2013) observations concerning the direction of net capital flows inside the "euro bloc". In addition, bureaucracy quality has a positive effect on intra balances: if the index increases by one standard deviation, a country tends to have a $1 \%$ (of GDP) larger (smaller) intra surplus (deficit). If a country experiences a 10\% increase in real unit labor costs relative to the other EU-15 countries, its intra balance will deteriorate by $1 \%$ (of GDP). If oil prices increase by 10 euros (per barrel), EU-15 countries will experience, on average, a $0.5 \%$ (of GDP) decrease in their extra balances. It is a bit strange that the government budget balance has a negative coefficient in the extra balance regression. However, this result is not robust for the different specifications. ${ }^{10}$

Current account imbalances or trade imbalances are always measured with respect to other countries; therefore, in the current account literature, the so-called rest of the world effect is usually taken into account using deviations from sample means. Hence, in model (5) we run regressions using deviations from the unweighted sample means. By comparing models (4) and (5), one can observe that our results are robust to this transformation, although naturally the values of the coefficients change.

In model (6), we provide preliminary empirical evidence that some dimensions of national culture are related to trade balances. ${ }^{11}$ We include Hofstede's (2001) individualism versus collectivism index into model (6). According to Gorodnichenko and Roland (2011), this cultural variable influences economic performance more robustly than other variables. ${ }^{12}$ If a country has an individualism score that is one standard deviation higher, its intra balance tends to be $2 \%$ (of GDP) higher. The individualism index seems to be unrelated to extra balances.

${ }^{10}$ Concerning Fiscal balance results for the period of 1981-2005 are well in line with Schmitz and von Hagen (2011, 1685, Table 4) (see Appendix A, Table 11).

${ }^{11}$ We tested other cultural dimensions by Hofstede (2001), but Uncertainty avoidance and Individualism indices were much more strongly related to intra balances than masculinity and power distance. Due to the fact that Uncertain avoidance index was strongly correlated with the

DKSEUK dummy (-0.711) we decided not to use it (see Appendix A, Table 10). However, results with Uncertainty avoidance can be found from the Appendix A, Table 14.

12 Hofstede $(2001,211)$ has made this same observation. 
Table 3

Regression results for trade balances and per capita incomes in Europe 1984-2011.

\begin{tabular}{|c|c|c|c|c|c|c|}
\hline \multirow[b]{2}{*}{ Variables: } & \multicolumn{3}{|c|}{$\begin{array}{l}\text { Dependent variable: } \\
\text { Intra balance }\end{array}$} & \multicolumn{3}{|c|}{$\begin{array}{l}\text { Dependent variable: } \\
\text { Extra balance }\end{array}$} \\
\hline & (4) & (5) & (6) & (4) & (5) & (6) \\
\hline \multirow[t]{2}{*}{ EMU } & -0.000 & 0.006 & 0.002 & -0.004 & $0.007^{*}$ & -0.004 \\
\hline & $(0.016)$ & $(0.004)$ & $(0.014)$ & $(0.014)$ & $(0.004)$ & $(0.015)$ \\
\hline \multirow[t]{2}{*}{ DKSEUK } & $0.038^{* *}$ & $-0.017^{*}$ & -0.023 & 0.021 & 0.007 & 0.028 \\
\hline & $(0.015)$ & $(0.009)$ & $(0.019)$ & $(0.016)$ & $(0.008)$ & $(0.017)$ \\
\hline \multirow[t]{2}{*}{ Non-EMU } & 0.002 & $-0.009^{*}$ & 0.010 & -0.003 & 0.008 & -0.004 \\
\hline & $(0.014)$ & $(0.005)$ & $(0.013)$ & $(0.020)$ & $(0.005)$ & $(0.021)$ \\
\hline \multirow[t]{2}{*}{ GDP per capita } & $0.034^{* * *}$ & $0.025^{* * *}$ & $0.019^{* * *}$ & $0.020 * * *$ & $0.030^{* * *}$ & $0.023^{* * *}$ \\
\hline & $(0.006)$ & $(0.008)$ & $(0.006)$ & $(0.006)$ & $(0.008)$ & $(0.007)$ \\
\hline \multirow[t]{2}{*}{ GDP per capita*EMU } & -0.001 & 0.010 & 0.001 & 0.002 & -0.004 & 0.002 \\
\hline & $(0.007)$ & $(0.007)$ & $(0.006)$ & $(0.007)$ & $(0.007)$ & $(0.007)$ \\
\hline \multirow[t]{2}{*}{ GDP per capita*DKSEUK } & $-0.028^{* * *}$ & -0.015 & -0.008 & -0.004 & -0.003 & -0.006 \\
\hline & $(0.007)$ & $(0.010)$ & $(0.008)$ & $(0.007)$ & $(0.011)$ & $(0.007)$ \\
\hline \multirow{2}{*}{ GDP per capita*Non-EMU } & -0.002 & -0.003 & -0.007 & 0.003 & -0.001 & 0.003 \\
\hline & $(0.006)$ & $(0.007)$ & $(0.006)$ & $(0.007)$ & $(0.008)$ & $(0.008)$ \\
\hline \multirow[t]{2}{*}{ Fiscal balance } & -0.014 & 0.008 & 0.005 & $-0.069^{*}$ & -0.066 & $-0.071^{*}$ \\
\hline & $(0.043)$ & $(0.052)$ & $(0.043)$ & $(0.041)$ & $(0.052)$ & $(0.041)$ \\
\hline \multirow[t]{2}{*}{ Oil price } & -0.007 & 0.003 & -0.004 & $-0.045^{* * *}$ & $-0.036^{* * *}$ & $-0.045^{* * *}$ \\
\hline & $(0.009)$ & $(0.006)$ & $(0.009)$ & $(0.010)$ & $(0.008)$ & $(0.010)$ \\
\hline \multirow{2}{*}{ Dependency ratio (aged) } & $-0.575^{* * *}$ & $-0.559^{* * *}$ & $-0.529 * * *$ & 0.008 & 0.066 & 0.006 \\
\hline & $(0.137)$ & $(0.168)$ & $(0.129)$ & $(0.122)$ & $(0.133)$ & $(0.118)$ \\
\hline \multirow[t]{2}{*}{ Dependency ratio (child) } & $0.438^{* * *}$ & $0.410^{* * *}$ & $0.355^{* * *}$ & -0.054 & -0.053 & -0.040 \\
\hline & $(0.105)$ & $(0.111)$ & $(0.099)$ & $(0.102)$ & $(0.102)$ & $(0.102)$ \\
\hline \multirow[t]{2}{*}{ Domestic credit by banks } & $0.018^{* * *}$ & $0.019 * * *$ & $0.021^{* * *}$ & $-0.021^{* * *}$ & $-0.022^{* * *}$ & $-0.022^{* * *}$ \\
\hline & $(0.006)$ & $(0.007)$ & $(0.006)$ & $(0.006)$ & $(0.007)$ & $(0.006)$ \\
\hline \multirow[t]{2}{*}{ Bureaucracy quality } & $0.019^{* * *}$ & $0.017^{* * *}$ & $0.008^{* *}$ & 0.005 & 0.005 & $0.007^{*}$ \\
\hline & $(0.004)$ & $(0.004)$ & $(0.004)$ & $(0.004)$ & $(0.004)$ & $(0.004)$ \\
\hline \multirow[t]{2}{*}{ Real interest rate } & -0.058 & -0.032 & $-0.077^{*}$ & -0.031 & 0.017 & -0.027 \\
\hline & $(0.043)$ & $(0.048)$ & $(0.044)$ & $(0.044)$ & $(0.052)$ & $(0.044)$ \\
\hline \multirow[t]{2}{*}{ Change in RULC } & $-0.084^{* *}$ & $-0.090^{* *}$ & $-0.087^{* *}$ & -0.021 & -0.037 & -0.023 \\
\hline & $(0.040)$ & $(0.040)$ & $(0.039)$ & $(0.041)$ & $(0.044)$ & $(0.042)$ \\
\hline \multirow[t]{2}{*}{ Hofstede's individualism } & & & $0.174^{* * *}$ & & & -0.019 \\
\hline & & & $(0.019)$ & & & $(0.020)$ \\
\hline $\mathrm{R}^{2}$ & 0.370 & 0.352 & 0.490 & 0.196 & 0.201 & 0.202 \\
\hline Observations & 387 & 387 & 387 & 387 & 387 & 387 \\
\hline
\end{tabular}

In addition, all regressions include a constant. Notes: In model (5) we used deviations from unweighted sample means. Estimation was performed using the Prais-Winsten estimator with panel-corrected standard errors (panel-level heteroskedastic and correlated across panels, common AR(1) autocorrelation structure, which is estimated from the autocorrelation of residuals ( $x$ tpcse command in STATA with correlation(ar1) and rhotype(tscorr) options)). Panel-corrected standard errors are in parenthesis. * ${ }^{* *}$ and ${ }^{* * *}$ denote statistical significance at the 10, 5 and 1 percent levels.

In Section 1, we made an observation that some countries have positive intra balances but negative extra balances or vice versa. Now, we will use our regression model to explain some of these patterns. In Fig. 3, we represent graphically the contribution of different components for the intra balances. We employ model (5), which is similar to model (4) in all other aspects, but it is estimated using deviations from unweighted sample means. The actual numbers that we put into the regression equation are the country-specific 1999-2011 averages of these deviations. For the change in real unit labor costs, labeled drulc in the figure, we input the percentage change between 1999 and 2011. Fig. 4 is drawn in the same fashion for the extra balances. This analysis enables us to explain some of the patterns seen in Fig. 1-2. During the 
1999-2011 period, Ireland had a huge intra surplus (15.6\% of the GDP on average) but a smaller extra surplus (7.4\% of the GDP on average). Based on our regression analysis, dependency ratios are statistically significant only for the intra balances. Ireland had the lowest old dependency ratio (this variable has a negative effect on intra balance) and the highest child dependency ratio (this variable has a positive effect on intra balance) in our sample. The Netherlands had a positive intra balance, whereas its extra balance was negative. To some extent, this comes from the fact that the Netherlands has had the most developed banking sector. Domestic credit by banks, which we used as a proxy for the state of the domestic banking sector, contributes positively to intra balances and negatively to extra balances. Naturally, this explains only a small fraction of the difference in the Netherlands' intra and extra balances. Italy's intra balance was negative, but its extra balance was positive. Italy had the lowest bureaucracy quality in our sample. Bureaucracy quality contributes positively to intra balances but is statistically insignificant for extra balances.

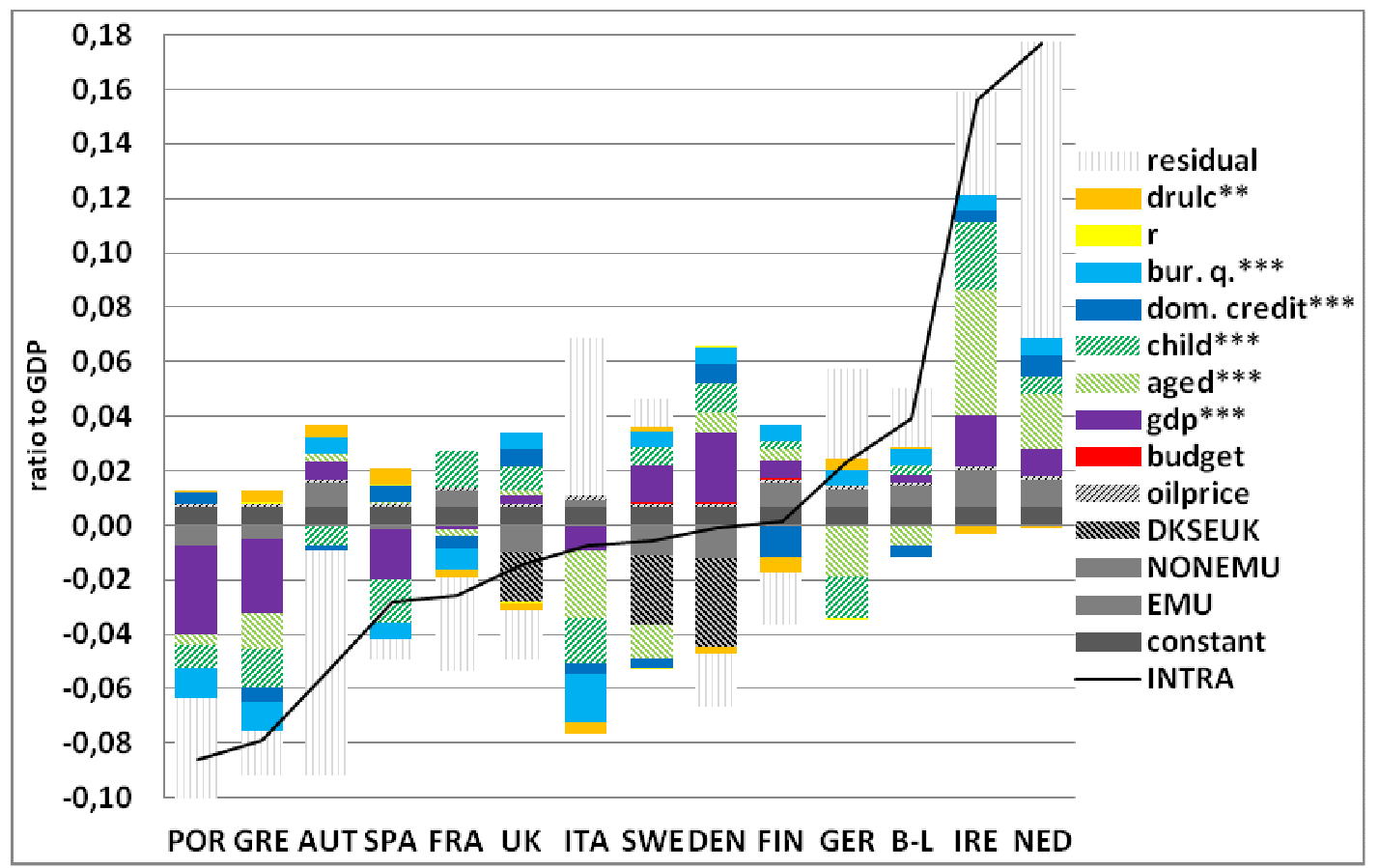

Fig. 3. Contribution of different components for the intra balances (model (5) and 1999-2011 averages). 


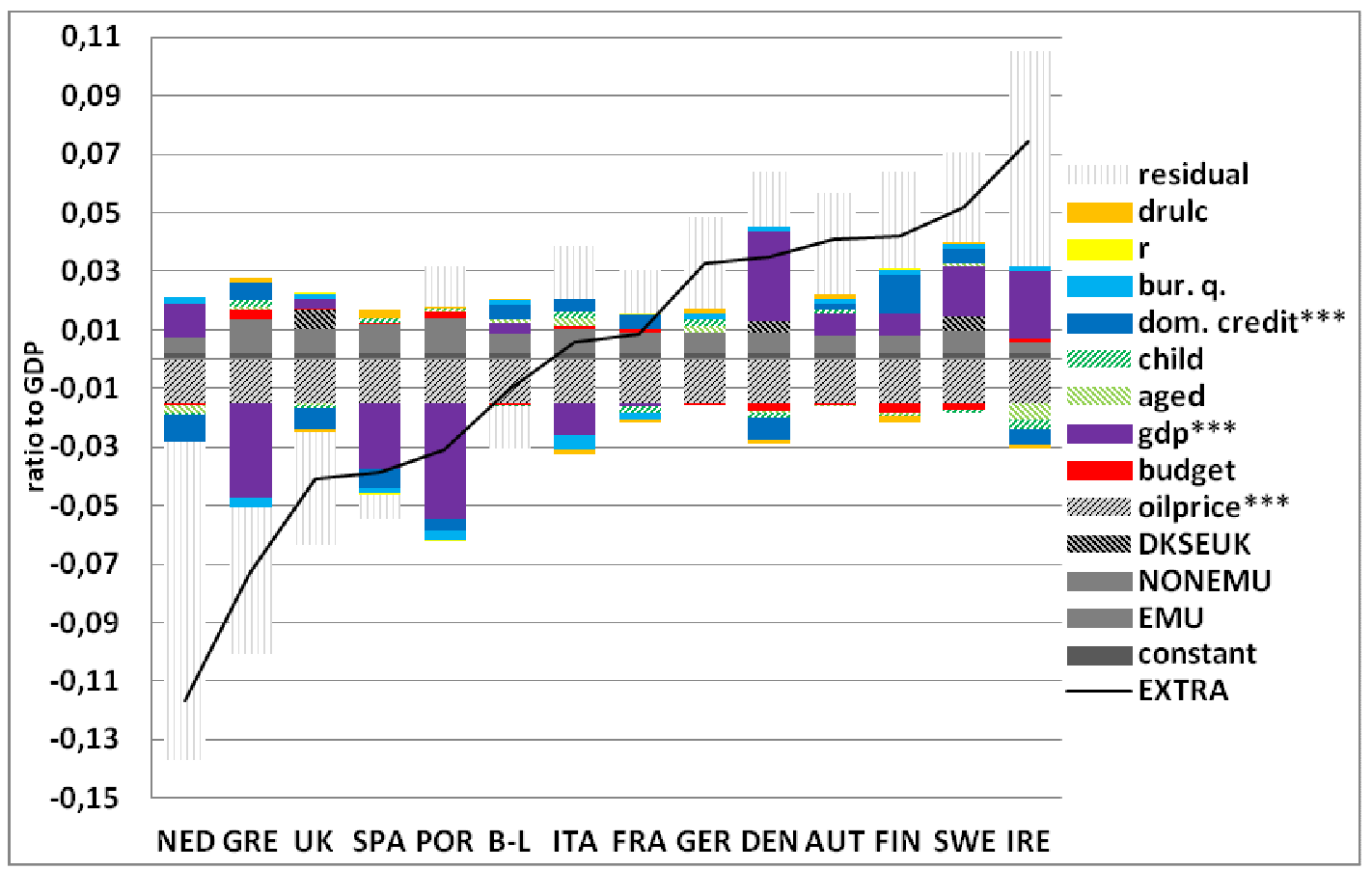

Fig. 4. Contribution of different components for the extra balances (model (5) and 1999-2011 averages).

\subsection{Robustness checks}

Fig. 3-4 indicate that the Netherlands is potentially an outlier in our sample. To some extent, this might result from the Rotterdam effect. For example, part of Germany's overseas imports are incorrectly recorded as Dutch overseas imports and then as a Germany's import from the Netherlands when goods are shipping via Rotterdam's port (see, e.g., Baldwin 2006, 59, and Flam and Nordström 2006, 6). Consequently, the Rotterdam effect has a tendency to increase Netherlands' intra exports and extra imports. In Fig 3-4, the Netherlands exhibits a large positive residual term in the intra balances and a large negative residual term in the extra balances. However, we are unable to detect how large fractions of these residuals are caused by the Rotterdam effect. The simplest way to control for the Rotterdam effect is to subtract trade with the Netherlands from the intra balances and to include a dummy variable for the Netherlands in both regressions. Naturally, this is a very crude thing to do because we are assuming that all intra trade between the Netherlands and rest of the EU-15 countries consist of transit between overseas countries and rest of the EU-15 countries. ${ }^{13}$ These results are shown in Table 4 . The statistical significance of the aged dependency ratio shifts to some extent from intra balances towards extra balances compared to Table 3. The statistical significance of domestic credit by banks becomes weaker; however, in model (8), it is still positively statistically significant at the 0.10 level. Finally, in model (8), Hofstede's individualism index becomes statistically significant and positive for the extra balances.

\footnotetext{
${ }^{13}$ A less crude way to control for the Rotterdam effect is to just add a dummy for the Netherlands, which is done in Appendix A, Table 12.
} 
Table 4

Regression results for trade balances and per capita incomes in Europe 1984-2011 (subtracting the trade with Netherlands from the intra balances).

\begin{tabular}{|c|c|c|c|c|}
\hline \multirow[b]{2}{*}{ Variables: } & \multicolumn{2}{|c|}{$\begin{array}{l}\text { Dependent variable: } \\
\text { Intra balance (sub- } \\
\text { tracting NED) }\end{array}$} & \multicolumn{2}{|c|}{$\begin{array}{l}\text { Dependent variable: } \\
\text { Extra balance }\end{array}$} \\
\hline & (7) & (8) & (7) & (8) \\
\hline EMU & $\begin{array}{l}-0.006 \\
(0.014)\end{array}$ & $\begin{array}{l}-0.005 \\
(0.013)\end{array}$ & $\begin{array}{l}0.002 \\
(0.016)\end{array}$ & $\begin{array}{l}0.002 \\
(0.015)\end{array}$ \\
\hline DKSEUK & $\begin{array}{l}0.028^{* *} \\
(0.014)\end{array}$ & $\begin{array}{l}-0.020 \\
(0.017)\end{array}$ & $\begin{array}{l}0.031^{*} \\
(0.016)\end{array}$ & $\begin{array}{l}0.019 \\
(0.018)\end{array}$ \\
\hline Non-EMU & $\begin{array}{l}0.003 \\
(0.013)\end{array}$ & $\begin{array}{l}0.008 \\
(0.012)\end{array}$ & $\begin{array}{l}-0.004 \\
(0.020)\end{array}$ & $\begin{array}{l}-0.003 \\
(0.019)\end{array}$ \\
\hline Netherlands & $\begin{array}{l}0.099 * * * \\
(0.017)\end{array}$ & $\begin{array}{l}0.076^{* * *} \\
(0.016)\end{array}$ & $\begin{array}{l}-0.098^{* * *} \\
(0.017)\end{array}$ & $\begin{array}{l}-0.104^{* * *} \\
(0.016)\end{array}$ \\
\hline GDP per capita & $\begin{array}{l}0.029^{* * *} \\
(0.006)\end{array}$ & $\begin{array}{l}0.018^{* * *} \\
(0.006)\end{array}$ & $\begin{array}{l}0.025^{\star * *} \\
(0.007)\end{array}$ & $\begin{array}{l}0.022^{* * *} \\
(0.007)\end{array}$ \\
\hline GDP per capita*EMU & $\begin{array}{l}0.003 \\
(0.006)\end{array}$ & $\begin{array}{l}0.004 \\
(0.006)\end{array}$ & $\begin{array}{l}-0.001 \\
(0.007)\end{array}$ & $\begin{array}{l}-0.001 \\
(0.007)\end{array}$ \\
\hline GDP per capita*DKSEUK & $\begin{array}{l}-0.022^{* * *} \\
(0.006)\end{array}$ & $\begin{array}{l}-0.008 \\
(0.007)\end{array}$ & $\begin{array}{l}-0.010 \\
(0.007)\end{array}$ & $\begin{array}{l}-0.006 \\
(0.007)\end{array}$ \\
\hline GDP per capita*Non-EMU & $\begin{array}{l}-0.002 \\
(0.005)\end{array}$ & $\begin{array}{l}-0.005 \\
(0.005)\end{array}$ & $\begin{array}{l}0.003 \\
(0.007)\end{array}$ & $\begin{array}{l}0.002 \\
(0.007)\end{array}$ \\
\hline Fiscal balance & $\begin{array}{l}-0.024 \\
(0.040)\end{array}$ & $\begin{array}{l}-0.011 \\
(0.040)\end{array}$ & $\begin{array}{l}-0.061 \\
(0.038)\end{array}$ & $\begin{array}{l}-0.057 \\
(0.038)\end{array}$ \\
\hline Oil price & $\begin{array}{l}-0.001 \\
(0.008)\end{array}$ & $\begin{array}{l}0.002 \\
(0.007)\end{array}$ & $\begin{array}{l}-0.051^{\text {*** }} \\
(0.011)\end{array}$ & $\begin{array}{l}-0.050^{* * *} \\
(0.010)\end{array}$ \\
\hline Dependency ratio (aged) & $\begin{array}{l}-0.216^{*} \\
(0.128)\end{array}$ & $\begin{array}{l}-0.232^{*} \\
(0.126)\end{array}$ & $\begin{array}{l}-0.346^{* * *} \\
(0.130)\end{array}$ & $\begin{array}{l}-0.348^{* * *} \\
(0.131)\end{array}$ \\
\hline Dependency ratio (child) & $\begin{array}{l}0.449^{* * *} \\
(0.098)\end{array}$ & $\begin{array}{l}0.362^{* * *} \\
(0.095)\end{array}$ & $\begin{array}{l}-0.065 \\
(0.093)\end{array}$ & $\begin{array}{l}-0.090 \\
(0.092)\end{array}$ \\
\hline Domestic credit by banks & $\begin{array}{l}0.007 \\
(0.005)\end{array}$ & $\begin{array}{l}0.010^{*} \\
(0.005)\end{array}$ & $\begin{array}{l}-0.009 \\
(0.006)\end{array}$ & $\begin{array}{l}-0.008 \\
(0.006)\end{array}$ \\
\hline Bureaucracy quality & $\begin{array}{l}0.016^{* * *} \\
(0.004)\end{array}$ & $\begin{array}{l}0.009 * * \\
(0.004)\end{array}$ & $\begin{array}{l}0.008^{*} \\
(0.004)\end{array}$ & $\begin{array}{l}0.006 \\
(0.004)\end{array}$ \\
\hline Real interest rate & $\begin{array}{l}-0.043 \\
(0.039)\end{array}$ & $\begin{array}{l}-0.060 \\
(0.039)\end{array}$ & $\begin{array}{l}-0.045 \\
(0.043)\end{array}$ & $\begin{array}{l}-0.049 \\
(0.043)\end{array}$ \\
\hline Change in RULC & $\begin{array}{l}-0.072^{*} \\
(0.038)\end{array}$ & $\begin{array}{l}-0.072^{* *} \\
(0.035)\end{array}$ & $\begin{array}{l}-0.033 \\
(0.037)\end{array}$ & $\begin{array}{l}-0.032 \\
(0.036)\end{array}$ \\
\hline Hofstede's individualism & & $\begin{array}{l}0.137^{* * *} \\
(0.015)\end{array}$ & & $\begin{array}{l}0.039^{* *} \\
(0.016)\end{array}$ \\
\hline $\mathrm{R}^{2}$ & 0.476 & 0.542 & 0.323 & 0.328 \\
\hline Observations & 387 & 387 & 387 & 387 \\
\hline
\end{tabular}

In addition, all regressions include a constant. Notes: Estimation was performed using the Prais-Winsten estimator with panel-corrected standard errors (panel-level heteroskedastic and correlated across panels, common AR(1) autocorrelation structure, which is estimated from the autocorrelation of residuals ( $x$ tpcse command in STATA with correlation(ar1) and rhotype(tscorr) options)). Panel-corrected standard errors are in parenthesis. ${ }^{*}, * *$ and ${ }^{* * *}$ denote statistical significance at the 10,5 and 1 percent levels.

To further check the robustness of our baseline results (model (4)), we exposed our specification to some testing. We included changes in target balances into our model because during the euro crisis, debtor countries financed their deficits through Target balances as private capital flew away. However, we were unable to find any statistically significant results for this variable, which is most likely because the im- 
portance of Target balances increased only recently (see Appendix A, Table 13, model (11)).

We also checked whether our results were robust to the manner in which the autocorrelation parameter was calculated or whether we allowed the autocorrelation parameter to be panel specific (see Appendix A, Table 13). None of these had an effect on our results. In addition, we performed the following test: We dropped interaction terms between country group dummies and GDP per capita from model (4) and instead included interaction terms between country group dummies and every explanatory variable one by one. ${ }^{14}$ We were unable to find a single case in which both the explanatory variable and its interaction term with the EMU dummy would have been statistically significant. Thus, our largely linear specification in model (4) is approved in this respect.

\section{Conclusions}

Schmitz and von Hagen (2011) provide evidence that the elasticity of net capital flows to per capita incomes within the euro area for the member countries increased as a result of the euro. When we augment their model using standard variables from the current account literature, we find out that this result largely disappears. However, their framework of analysis is fascinating; one can obtain some interesting new results by decomposing trade balance into intra balance (trade balance vis-à-vis the euro area) and extra balance (trade balance vis-à-vis the rest of the world). The child dependency ratio has a positive effect on intra balances but no effect or a negative effect on extra balances, whereas the aged dependency ratio has a negative effect on intra balances. These factors explain relatively well why Ireland has had a huge intra surplus but a smaller extra surplus.

The sophistication of the banking sector has a positive effect on intra balances but a negative effect on extra balances. This finding is very interesting as it helps us to understand why the countries with the most sophisticated financial markets have had positive intra balances and negative extra balances. These countries are effectively acting as financial intermediaries for the rest of the EMU countries. However, this result is, to some extent, sensitive to how the Netherlands and the possible Rotterdam effect have been tackled. Additionally, bureaucracy quality has a positive effect on intra balances. In the current account literature, both the quality of the domestic financial sector and the quality of government institutions are assumed to have negative effects on current account balances. In the world economy, there is a net capital flow from the poor developing countries to the US. In the euro area, capital tends to flow from the highly developed countries to the less developed countries. Our model is capable of capturing this phenomenon, indicating that the positive relation between the intra balances and the quality of domestic financial markets as well as the positive relation between the intra balances and the quality of government institutions has caused this to occur.

Our paper provides also preliminary evidence that some dimensions of national culture, such as individualism, are important for the intra balances and extra bal-

${ }^{14}$ In the interest of space, these are not reported. 
ances. Overall, our model seems to perform better in explaining intra balances than extra balances. It is very likely that with respect to extra balances, external factors, such as the euro's exchange rate, dominate.

For example, with respect to Greece and Portugal, which have had the largest cumulative trade deficits during the euro era, our model points a finger at their low relative income (the two poorest countries in our sample), low bureaucracy quality (the second and the third worst systems in our sample after Italy) and collectivistic culture (the two countries with the lowest individualism scores). ${ }^{15}$ Naturally reducing their real relative unit labor costs further might help also, although those are not above the long-run averages. For Portugal, a major part of its trade deficits has resulted from trade with the EMU countries. If, along the integration process, both its GDP per capita and bureaucracy quality converge to the EU-15 averages, its trade balance will become more balanced in the future. It will most likely take much longer for the national culture to change. Greece's trade deficit has resulted from both intra and extra trade. To improve its extra balance, Greece might need the euro to devalue and, consequently, for example, Germany's trade surplus vis-à-vis the rest of the world to decrease.

\section{Acknowledgements}

The author is grateful to Kari Heimonen, Michael G. Arghyrou, Tuomas Malinen, Maritta Paloviita, Mika Maliranta and the other participants at XXXI Annual Summer Seminar of Finnish Economists, 18 $8^{\text {th }}$ International Conference on Macroeconomic Analysis and International Finance, Finnish Economic Association XXXVI Annual Meeting, FDPE Macroeconomics Workshop I/2014, $8^{\text {th }}$ Allecon Seminar as well as Juha Junttila, Timo Tohmo, and an anonymous referee for their helpful comments. The author is thankful for the financial support provided by the Yrjö Jahnsson Foundation (Grant No. 6294), Björn Savén Finnish American Scholarship and OPPohjola Group Research Foundation. This study is part of the work of the JSBE Research Group on International Macro and Finance (JyIMaF).

\section{Appendix A. Supplementary data}

Supplementary data to this article can be found online.

\section{References}

Acemoglu, D. 2009. Introduction to modern economic growth, Princeton University Press, Princeton (NJ).

Acemoglu, D., Robinson, J. A. 2012. Why nations fail, Profile Books, London. Altug, S., Canova, F. 2014. Do institutions and culture matter for business cycles? Open Economies Rev. 25 (1), 98-122.

\footnotetext{
${ }^{15}$ Alternatively, Portugal and Greece were the two countries with the highest uncertainty avoidance scores.
} 
Arghyrou, M. G., Chortareas, G. 2008. Current account imbalances and real exchange rates in the euro area. Rev. Int. Econ. 9 (5), 747-764.

Baldwin, R. 2006. The euro's trade effects. ECB Working Paper Series No. 594.

Barnes, S., Lawson, J., Radziwill, A. 2010. Current account imbalances in the euro area: a comparative perspective. OECD Economics Department Working Papers No. 826.

Beck, N., Katz, J. N. 1995. What to do (and not to do) with time-series cross-section data. Amer. Polit. Sci. Rev. 89 (3), 634-647.

Belke, A., Dreger, C. 2013. Current account imbalances in the euro area: Does catching up explain the development? Rev. Int. Econ. 21 (1), 6-17.

Berger, H., Nitsch, V. 2010. The euro's effect on trade imbalances. IMF Working Paper 10/226.

Blanchard, O., Giavazzi, F. 2002. Current account deficits in the euro area: the end of the Feldstein-Horioka puzzle? Brookings Pap. Econ. Act. 2002:2, 147-209.

Ca' Zorzi, M., Chudik, A., Dieppe, A. 2012. Thousands of models, one story: current account imbalances in the global economy. J. Int. Money Finance 31 (6), 13191338.

Chen, R., Milesi-Ferretti, G. M., Tressel, T. 2013. External imbalances in the eurozone. Econ. Policy 28 (73), 101-142.

Chinn, M., Ito, H. 2007. Current account balances, financial development and institutions: assaying the world "saving glut". J. Int. Money Finance 26 (4), 546569.

Chinn, M., Prasad, E. 2003. Medium-term determinants of current accounts in industrial and developing countries: an empirical exploration. J. Int. Econ. 59 (1), 47-76.

Cour-Thimann, P. 2013. Target balances and the crisis in the euro area. CESifo Forum 14 Special issue 1, Ifo Institute, Munich, 2013, 5-50.

De Castro Campos, M., Kool, C., Muysken, J. 2013. Cross-country private saving heterogeneity and culture. De Economist 161 (2), 101-120.

Eichengreen, B. 2010. Imbalances in the euro area. Unpublished working paper. <http:/ / eml.berkeley.edu/ eichengr/Imbalances_Euro_Area_5-23-11.pdf>. 16.6.2014.

Flam, H., Nordstöm, H. 2006. Trade volume effects of the euro: aggregate and sector estimates. IIES Seminar Paper No. 746.

Giavazzi, F., Spaventa, L. 2010. Why the current account may matter in a monetary union: lessons from the financial crisis in the euro area, in: Beblavý, M., Cobham, D., Ódor, L. (Eds.), 2011. The euro area and the financial crisis. Cambridge University Press.

Gorodnichenko, Y. Roland, G. 2010. Culture, institutions and the wealth of nations. NBER Working Paper Series No. 16368.

Gorodnichenko, Y., Roland, G. 2011. Which dimensions of culture matter for longrun growth? Amer. Econ. Rev., Papers and Proceedings, 101 (3) 492-498.

Greif, A. 1994. Cultural beliefs and the organization of society: a historical and theoretical reflection on collectivist and individualist societies. J. Polit. Economy 102 (5), 919-950. 
Gruber, J., Kamin, S. 2007. Explaining the global pattern of current account imbalances. J. Int. Money Finance 26 (4), 500-522.

Hofstede, G. 2001. Culture's consequences: comparing values, behaviors, institutions, and organizations across nations, $2^{\text {nd }}$ edition, Saga Publications.

Holinski, N., Kool, C., Muysken, J. 2012. Persistent macroeconomic imbalances in the euro area: causes and consequences. Federal Reserve Bank of St. Louis Review, January/February 2012.

<http://www.sustainablefinancelab.nl/files/2012/04/Persistent-

Macroeconomic-Imbalances.pdf> 3.10.2013.

International Monetary Fund. 2006. Methodology for CGER exchange rate assessments. <http://www.imf.org/external/np/pp/eng/2006/110806.pdf>. 17.10.2013.

Jaumotte, F., Sodsriwiboon, P. 2010. Current account imbalances in the southern euro area. IMF Working Paper, WP/10/139.

Landes, D. 1999. The wealth and poverty of nations. W. W. Norton \& Company, New York (NY).

Maseland, R. 2013. Parasitical cultures? The cultural origins of institutions and development. J. Econ. Growth 18 (2), 109-136.

Schmitz, B., von Hagen, J. 2011. Current account imbalances and financial integration in the euro area. J. Int. Money Finance 30 (8), 1676-1695.

Schnabl, G., Freitag, S. 2012. Reserve causality in global and intra-European imbalances. Rev. Int. Econ. 20 (4), 674-690.

Sinn, H.-W., Wollmershäuser, T. 2012. Target loans, current account balances and capital flows: the ECB's rescue facility. Int. Tax Public Finance 19, 468-508.

Slavov, S. 2009. Do common currencies facilitate the net flow of capital among countries? N. Amer. J. of Econ. Finance 20 (2), 124-144.

Tabellini, G. 2010. Culture and institutions: economic development in the regions of Europe. J. Eur. Econ. Assoc. 8 (4), 677-716.

Weil, D. 2009. Economic growth, 2nd edition, Pearson, Boston (MA). 


\section{Appendix A. Supplementary data (can be found online)}

Table 5

Intra balances and extra balances (ratio to GDP) for the EU-15 countries during the period of 1984-2011.

\begin{tabular}{|c|c|c|c|c|}
\hline Country & 1984 & 1993 & 2002 & 2011 \\
\hline $\begin{array}{ll}\text { Austria } & \text { (Intra balance) } \\
& \text { (Extra balance) }\end{array}$ & $\begin{array}{l}-0.055 \\
-0.003\end{array}$ & $\begin{array}{l}-0.038 \\
-0.006\end{array}$ & $\begin{array}{l}-0.031 \\
0.033\end{array}$ & $\begin{array}{l}-0.068 \\
0.028\end{array}$ \\
\hline Bel-Lux & $\begin{array}{l}-0.020 \\
-0.021\end{array}$ & $\begin{array}{l}0.039 \\
-0.006\end{array}$ & $\begin{array}{l}0.027 \\
0.021\end{array}$ & $\begin{array}{l}0.015 \\
-0.023\end{array}$ \\
\hline Denmark & $\begin{array}{l}-0.030 \\
0.018\end{array}$ & $\begin{array}{l}0.015 \\
0.031\end{array}$ & $\begin{array}{l}-0.002 \\
0.045\end{array}$ & $\begin{array}{l}-0.004 \\
0.042\end{array}$ \\
\hline Finland & $\begin{array}{l}-0.006 \\
0.027\end{array}$ & $\begin{array}{l}0.018 \\
0.042\end{array}$ & $\begin{array}{l}0.027 \\
0.058\end{array}$ & $\begin{array}{l}-0.024 \\
0.000\end{array}$ \\
\hline France & $\begin{array}{l}-0.012 \\
-0.001\end{array}$ & $\begin{array}{l}0.002 \\
0.009\end{array}$ & $\begin{array}{l}-0.016 \\
0.018\end{array}$ & $\begin{array}{l}-0.041 \\
-0.001\end{array}$ \\
\hline Germany & $\begin{array}{l}0.013 \\
0.013\end{array}$ & $\begin{array}{l}0.009 \\
0.009\end{array}$ & $\begin{array}{l}0.028 \\
0.032\end{array}$ & $\begin{array}{l}0.007 \\
0.035\end{array}$ \\
\hline Greece & $\begin{array}{l}-0.042 \\
-0.059\end{array}$ & $\begin{array}{l}-0.053 \\
-0.055\end{array}$ & $\begin{array}{l}-0.075 \\
-0.069\end{array}$ & $\begin{array}{l}-0.053 \\
-0.048\end{array}$ \\
\hline Ireland & $\begin{array}{l}0.060 \\
-0.061\end{array}$ & $\begin{array}{l}0.144 \\
0.006\end{array}$ & $\begin{array}{l}0.188 \\
0.106\end{array}$ & $\begin{array}{l}0.149 \\
0.101\end{array}$ \\
\hline Italy & $\begin{array}{l}-0.010 \\
-0.016\end{array}$ & $\begin{array}{l}0.007 \\
0.014\end{array}$ & $\begin{array}{l}-0.008 \\
0.014\end{array}$ & $\begin{array}{l}-0.010 \\
0.005\end{array}$ \\
\hline Netherlands & $\begin{array}{l}0.094 \\
-0.068\end{array}$ & $\begin{array}{l}0.077 \\
-0.031\end{array}$ & $\begin{array}{l}0.142 \\
-0.086\end{array}$ & $\begin{array}{l}0.244 \\
-0.171\end{array}$ \\
\hline Portugal & $\begin{array}{l}-0.018 \\
-0.093\end{array}$ & $\begin{array}{l}-0.063 \\
-0.033\end{array}$ & $\begin{array}{l}-0.074 \\
-0.023\end{array}$ & $\begin{array}{l}-0.066 \\
-0.025\end{array}$ \\
\hline Spain & $\begin{array}{l}0.011 \\
-0.042\end{array}$ & $\begin{array}{l}-0.014 \\
-0.024\end{array}$ & $\begin{array}{l}-0.028 \\
-0.025\end{array}$ & $\begin{array}{l}-0.008 \\
-0.040\end{array}$ \\
\hline Sweden & $\begin{array}{l}0.000 \\
0.022\end{array}$ & $\begin{array}{l}0.008 \\
0.029\end{array}$ & $\begin{array}{l}-0.001 \\
0.063\end{array}$ & $\begin{array}{l}-0.022 \\
0.026\end{array}$ \\
\hline UK & $\begin{array}{l}-0.014 \\
-0.010\end{array}$ & $\begin{array}{l}-0.007 \\
-0.018\end{array}$ & $\begin{array}{l}-0.007 \\
-0.029\end{array}$ & $\begin{array}{l}-0.022 \\
-0.050\end{array}$ \\
\hline
\end{tabular}


Table 6

Share of intra trade of total trade (excluding services) for the EU-15 countries during the period of 1984-2011. ${ }^{\mathrm{a}}$

\begin{tabular}{|c|c|c|c|c|}
\hline Country & 1984 & 1993 & 2002 & 2011 \\
\hline $\begin{array}{ll}\text { Austria } & \text { (Exports) } \\
& \text { (Imports) }\end{array}$ & $\begin{array}{l}0.506 \\
0.594\end{array}$ & $\begin{array}{l}0.606 \\
0.650\end{array}$ & $\begin{array}{l}0.546 \\
0.632\end{array}$ & $\begin{array}{l}0.504 \\
0.610\end{array}$ \\
\hline Belgium & & & $\begin{array}{l}0.609 \\
0.611\end{array}$ & $\begin{array}{l}0.606 \\
0.575\end{array}$ \\
\hline Denmark & $\begin{array}{l}0.346 \\
0.435\end{array}$ & $\begin{array}{l}0.460 \\
0.489\end{array}$ & $\begin{array}{l}0.433 \\
0.506\end{array}$ & $\begin{array}{l}0.384 \\
0.448\end{array}$ \\
\hline Finland & $\begin{array}{l}0.235 \\
0.281\end{array}$ & $\begin{array}{l}0.343 \\
0.354\end{array}$ & $\begin{array}{l}0.327 \\
0.330\end{array}$ & $\begin{array}{l}0.289 \\
0.342\end{array}$ \\
\hline France & $\begin{array}{l}0.434 \\
0.466\end{array}$ & $\begin{array}{l}0.489 \\
0.514\end{array}$ & $\begin{array}{l}0.491 \\
0.565\end{array}$ & $\begin{array}{l}0.482 \\
0.563\end{array}$ \\
\hline Germany & $\begin{array}{l}0.456 \\
0.450\end{array}$ & $\begin{array}{l}0.453 \\
0.448\end{array}$ & $\begin{array}{l}0.426 \\
0.415\end{array}$ & $\begin{array}{l}0.403 \\
0.432\end{array}$ \\
\hline Greece & $\begin{array}{l}0.494 \\
0.461\end{array}$ & $\begin{array}{l}0.541 \\
0.513\end{array}$ & $\begin{array}{l}0.304 \\
0.457\end{array}$ & $\begin{array}{l}0.280 \\
0.398\end{array}$ \\
\hline Ireland & $\begin{array}{l}0.359 \\
0.238\end{array}$ & $\begin{array}{l}0.402 \\
0.205\end{array}$ & $\begin{array}{l}0.383 \\
0.203\end{array}$ & $\begin{array}{l}0.402 \\
0.240\end{array}$ \\
\hline Italy & $\begin{array}{l}0.427 \\
0.423\end{array}$ & $\begin{array}{l}0.490 \\
0.513\end{array}$ & $\begin{array}{l}0.445 \\
0.499\end{array}$ & $\begin{array}{l}0.409 \\
0.443\end{array}$ \\
\hline Netherlands & $\begin{array}{l}0.638 \\
0.472\end{array}$ & $\begin{array}{l}0.634 \\
0.496\end{array}$ & $\begin{array}{l}0.631 \\
0.418\end{array}$ & $\begin{array}{l}0.619 \\
0.339\end{array}$ \\
\hline Portugal & $\begin{array}{l}0.473 \\
0.367\end{array}$ & $\begin{array}{l}0.641 \\
0.647\end{array}$ & $\begin{array}{l}0.666 \\
0.698\end{array}$ & $\begin{array}{l}0.636 \\
0.660\end{array}$ \\
\hline Spain & $\begin{array}{l}0.425 \\
0.286\end{array}$ & $\begin{array}{l}0.603 \\
0.547\end{array}$ & $\begin{array}{l}0.582 \\
0.569\end{array}$ & $\begin{array}{l}0.535 \\
0.465\end{array}$ \\
\hline Sweden & $\begin{array}{l}0.412 \\
0.448\end{array}$ & $\begin{array}{l}0.454 \\
0.499\end{array}$ & $\begin{array}{l}0.394 \\
0.489\end{array}$ & $\begin{array}{l}0.388 \\
0.463\end{array}$ \\
\hline UK & $\begin{array}{l}0.468 \\
0.480\end{array}$ & $\begin{array}{l}0.485 \\
0.460\end{array}$ & $\begin{array}{l}0.525 \\
0.468\end{array}$ & $\begin{array}{l}0.463 \\
0.418\end{array}$ \\
\hline
\end{tabular}

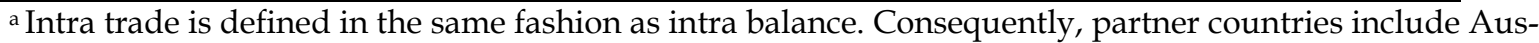
tria, Belgium-Luxembourg, Finland, France, Germany, Greece, Ireland, Italy, Netherlands, Portugal, and Spain. 
Table 7

Data description.

\begin{tabular}{|c|c|c|}
\hline Variable & Description & Source ${ }^{\mathrm{a}}$ \\
\hline $\begin{array}{l}\text { Bilateral trade } \\
\text { balances }\end{array}$ & $\begin{array}{l}\text { Trade balance (ratio to GDP) excluding services } \\
\text { against the euro area; Trade balance excluding ser- } \\
\text { vices against the rest of the world }\end{array}$ & DOTS/WDI ${ }^{16}$ \\
\hline GDP per capita & $\begin{array}{l}\text { Gross domestic product at current market prices per } \\
\text { head of population (1000 EUR) divided by 10, } \\
\text { "HVGDP" }\end{array}$ & $\mathrm{AMECO}^{17}$ \\
\hline Fiscal balance & $\begin{array}{l}\text { Net lending (Mrd EUR) “UBLG" divided by Gross } \\
\text { domestic product at current prices (Mrd ECU/EUR) } \\
\text { "UVGD" }\end{array}$ & $\begin{array}{l}\text { AMECO17, WEO, } \\
\text { GFS, IFS yearbook } \\
1998\end{array}$ \\
\hline Oil price & $\begin{array}{l}\text { Crude oil dated brent U\$/BBL divided by the US to } \\
\text { euro exchange rate multiplied by } 0.01\end{array}$ & $\begin{array}{l}\text { Datastream (Thom- } \\
\text { son Reuters) }\end{array}$ \\
\hline Dependency ratios & $\begin{array}{l}\text { Number of people aged } 65 \text { or more (or aged } 0-14 \text { ) } \\
\text { divided by the number of people aged } 15-64\end{array}$ & $\mathrm{WDI}^{18}$ \\
\hline $\begin{array}{l}\text { Domestic credit by } \\
\text { banks }\end{array}$ & $\begin{array}{l}\text { Domestic credit provided by banking sector (ratio to } \\
\text { GDP) }\end{array}$ & $\mathrm{WDI}^{18}$ \\
\hline Bureaucracy quality & $\begin{array}{l}\text { International Country Risk Guide: The political risk } \\
\text { components: Bureaucracy quality }\end{array}$ & PRS17 \\
\hline Real interest rate & Real short-term interest rates, deflator GDP "ISRV" & $\mathrm{AMECO}^{18}$ \\
\hline Change in RULC & $\begin{array}{l}\text { Change }(0.01 \text { denotes } 1 \%) \text { in real unit labour costs: } \\
\text { total economy (performance relative to the rest of the } \\
\text { former EU-15: double export weights }(2005=100) \\
\text { "QLCDQ" }\end{array}$ & $\mathrm{AMECO}^{18}$ \\
\hline $\begin{array}{l}\text { Hofstede's } \\
\text { individualism }\end{array}$ & $\begin{array}{l}\text { Hofstede's dimensions of national cultures: } \\
\text { Individualism (high values) versus collectivism (low } \\
\text { values) }\end{array}$ & Hofstede $^{18}$ \\
\hline $\begin{array}{l}\text { Change in Target } \\
\text { balances }\end{array}$ & $\begin{array}{l}\text { Change in Target balances divided by the GDP (cur- } \\
\text { rent LCU) }\end{array}$ & CESifo/WDI ${ }^{19}$ \\
\hline
\end{tabular}

a AMECO: Annual macro-economic database of the European Commission's Directorate General for Economic and Financial Affairs; CESifo:

<http://www.cesifo-group.de/dms/ifodoc/docs/politikdebatte/C_Haftungspegel/Targetcountries/Target-countries-2013-10-07.xls>. 3.9.2013; DOTS: Direction of Trade Statistics, International Monetary Fund; GFS: Government Finance Statistics; Hofstede:

<http://www.geerthofstede.com/media/651/6\%20dimensions\%20for\%20website.xls>. 8.4.2013; IFS yearbook: International Financial Statistics Yearbook 1998; PRS: Political Risk Services' International Country Risk Guide (Table 3B); WEO: World Economic Outlook Database, October 2010; WDI: World Development Indicators, The World Bank.

${ }^{16}$ Intra balance was calculated by summing up the bilateral trade balances with respect to Austria, Belgium, Luxembourg, Finland, France, Germany, Greece, Ireland, Italy, Netherlands, Portugal and Spain (not by using "Euro Area" as a partner country). Extra balance was calculated as a remainder of bilateral trade balance with respect to World and intra balance. Both of these numbers were divided by GDP (current US\$) from WDI.

${ }^{17}$ For Belgium-Luxembourg values of Belgium was used and for Germany between 1984-1990 values of West Germany was used.

${ }^{18}$ For Belgium-Luxembourg values of Belgium was used.

${ }^{19}$ GDP is from WDI. We created zeros for Austria, Belgium-Luxembourg, Finland, France, Germany, Ireland, Italy, Netherlands, Portugal and Spain from 1984 to 1998 (pre-euro period), for Greece from 1984 to 2000 (pre-euro period), and for Denmark, Sweden and UK from 1984 to 2011 (the whole period). 
Hofstede's (2001) description of the individualism index:

Individualism stands for a society in which the ties between individuals are loose: Everyone is expected to look after him/herself and her/his immediate family only. Collectivism stands for a society in which people from birth onwards are integrated into strong, cohesive in-groups, which throughout people's lifetime continue to protect them in exchange for unquestioning loyalty. (Hofstede 2001, 225)

The list of countries in the sample: Austria (adopted euro in 1999), BelgiumLuxembourg (adopted euro in 1999), Denmark, Finland (adopted euro in 1999), France (adopted euro in 1999), Germany (adopted euro in 1999), Greece (adopted euro in 2001), Ireland (adopted euro in 1999), Italy (adopted euro in 1999), Netherlands (adopted euro in 1999), Portugal (adopted euro in 1999), Spain (adopted euro in 1999), Sweden, United Kingdom.

\section{Table 8}

Omitting observations.

\begin{tabular}{|c|c|c|c|}
\hline Variable & $\begin{array}{l}\text { Number of lacking } \\
\text { annual observa- } \\
\text { tions }\end{array}$ & Lacking observations & Created values \\
\hline Intra balance & $0 / 392$ & & \\
\hline Extra balance & $0 / 392$ & & \\
\hline GDP per capita & $0 / 392$ & & \\
\hline Fiscal balance & $5 / 392$ & $\begin{array}{l}\text { Greece 1984-1987, Ireland } \\
1984\end{array}$ & \\
\hline Oil price & $0 / 28$ & & \\
\hline $\begin{array}{l}\text { Dependency ratio } \\
\text { (aged) }\end{array}$ & $0 / 392$ & & \\
\hline $\begin{array}{l}\text { Dependency ratio } \\
\text { (child) }\end{array}$ & $0 / 392$ & & \\
\hline $\begin{array}{l}\text { Domestic credit by } \\
\text { banks }\end{array}$ & $4 / 392$ & $\begin{array}{l}\text { Austria 1998, Belgium- } \\
\text { Luxembourg 1998, France } \\
\text { 1998, Netherlands } 1998\end{array}$ & $\begin{array}{l}\text { Austria 1998, Belgium- } \\
\text { Luxembourg 1998, France } \\
\text { 1998, Netherlands } 1998\end{array}$ \\
\hline Bureaucracy quality & $0 / 392$ & & \\
\hline Real interest rate & 0/392 & & \\
\hline Change in RULC & $0 / 392$ & & \\
\hline $\begin{array}{l}\text { Hofstede's } \\
\text { individualism }\end{array}$ & $0 / 14$ & & \\
\hline $\begin{array}{l}\text { Change in Target } \\
\text { balances }\end{array}$ & $0 / 141$ & \multicolumn{2}{|c|}{$\begin{array}{l}\text { zero (euro countries during the pre-euro period and } \\
\text { DKSEUK during the whole period) }\end{array}$} \\
\hline
\end{tabular}

Table 9

Data for the figures and tables.

\begin{tabular}{lll}
\hline Figure & Variable / Code & Source \\
\hline Fig. 1-2 & Trade balances / GDP & DOTS / WDI \\
Fig. 1-2 & Shape file & Downloaded from \\
& (TM_WORLD_BORDERS_SIMPL- & <http://thematicmapping.org/downloads/worl \\
& 0.3.zip package) & d_borders.php >. 26.11.2012. \\
Tables 5-6 & Trade balances / GDP & DOTS / WDI \\
Table 6 & Current account balances & WDI, WEO \\
\hline
\end{tabular}


Table 10

Correlation matrix (calculated without created values, 383 observations).

\begin{tabular}{|c|c|c|c|c|c|c|c|c|c|c|c|c|c|c|c|c|}
\hline Variable & $\begin{array}{l}\text { Intra } \\
\text { bal }\end{array}$ & $\begin{array}{l}\text { Extra } \\
\text { bal }\end{array}$ & EMU & $\begin{array}{l}\text { DKSE } \\
\text { UK }\end{array}$ & $\begin{array}{l}\text { Non- } \\
\text { EMU }\end{array}$ & $\begin{array}{l}\text { GDP } \\
\text { per } \\
\text { capita }\end{array}$ & $\begin{array}{l}\text { Fiscal } \\
\text { bal }\end{array}$ & $\begin{array}{l}\text { Oil } \\
\text { price }\end{array}$ & $\begin{array}{l}\text { Dep. } \\
\text { Ratio } \\
\text { aged }\end{array}$ & $\begin{array}{l}\text { Dep. } \\
\text { Ratio } \\
\text { child }\end{array}$ & $\begin{array}{l}\text { Dom. } \\
\text { credit } \\
\text { by } \\
\text { banks }\end{array}$ & $\begin{array}{l}\text { Bu- } \\
\text { reau- } \\
\text { cracy }\end{array}$ & $\begin{array}{l}\text { Real } \\
\text { inter- } \\
\text { est } \\
\text { rate }\end{array}$ & $\begin{array}{l}\text { Chang } \\
\text { e in } \\
\text { rulc }\end{array}$ & $\begin{array}{l}\text { Hof- } \\
\text { stede } \\
\text { IDV }\end{array}$ & $\begin{array}{l}\text { Chang } \\
\text { e in } \\
\text { Target }\end{array}$ \\
\hline Intra balance & 1 & & & & & & & & & & & & & & & \\
\hline EMU & 0.093 & -0.034 & 1 & & & & & & & & & & & & & \\
\hline DKSEUK & -0.093 & 0.221 & -0.405 & 1 & & & & & & & & & & & & \\
\hline Non-EMU & -0.084 & 0.125 & -0.264 & 0.612 & 1 & & & & & & & & & & & \\
\hline GDP per capita & 0.315 & 0.374 & 0.436 & 0.271 & 0.433 & 1 & & & & & & & & & & \\
\hline Oil price & -0.003 & -0.047 & 0.569 & -0.006 & 0.236 & 0.585 & 0.037 & 1 & & & & & & & & \\
\hline Dep. ratio (aged) & -0.443 & 0.080 & 0.354 & 0.264 & 0.186 & 0.321 & 0.062 & 0.414 & 1 & & & & & & & \\
\hline Dep. ratio (child) & 0.397 & -0.006 & -0.392 & 0.094 & 0.015 & -0.246 & -0.046 & -0.273 & -0.599 & 1 & & & & & & \\
\hline Domestic credit & 0.137 & -0.160 & 0.370 & 0.089 & 0.315 & 0.543 & -0.077 & 0.595 & 0.243 & -0.280 & 1 & & & & & \\
\hline Bureaucracy quality & 0.435 & 0.372 & -0.137 & 0.347 & 0.195 & 0.466 & 0.391 & -0.046 & -0.119 & 0.088 & 0.073 & 1 & & & & \\
\hline Real interest rate & -0.020 & 0.012 & -0.563 & 0.078 & -0.171 & -0.444 & -0.170 & -0.477 & -0.331 & 0.314 & -0.422 & 0.143 & 1 & & & \\
\hline Change in RULC & -0.107 & -0.009 & -0.008 & 0.068 & 0.015 & 0.082 & 0.134 & -0.008 & 0.036 & -0.069 & -0.002 & 0.007 & 0.164 & 1 & & \\
\hline Hofstede IDV & 0.532 & 0.218 & -0.165 & 0.422 & 0.232 & 0.418 & 0.206 & -0.005 & -0.017 & 0.162 & 0.082 & 0.612 & 0.115 & 0.034 & 1 & \\
\hline
\end{tabular}


Table 11

Regression results for trade balances and per capita incomes in Europe 1981-2005.

\begin{tabular}{|c|c|c|c|c|}
\hline \multirow[b]{2}{*}{ Variables: } & \multicolumn{2}{|c|}{$\begin{array}{l}\text { Dependent variable: } \\
\text { Intra balance }\end{array}$} & \multicolumn{2}{|c|}{$\begin{array}{l}\text { Dependent variable: } \\
\text { Extra balance }\end{array}$} \\
\hline & $\begin{array}{l}\text { PW-OLS } \\
\text { with PCSE }\end{array}$ & FE & $\begin{array}{l}\text { PW-OLS } \\
\text { with PCSE }\end{array}$ & $\mathrm{FE}$ \\
\hline \multirow[t]{2}{*}{ EMU } & $-0.074^{* *}$ & $-0.058^{* * *}$ & $-0.022^{* *}$ & -0.023 \\
\hline & $(0.030)$ & $(0.019)$ & $(0.011)$ & $(0.033)$ \\
\hline \multirow[t]{2}{*}{ DKSEUK } & $0.020^{*}$ & & $0.045^{\star * *}$ & \\
\hline & $(0.012)$ & & $(0.009)$ & \\
\hline \multirow{2}{*}{ Non-EMU } & -0.039 & $-0.027^{* *}$ & -0.008 & -0.027 \\
\hline & $(0.026)$ & $(0.010)$ & $(0.016)$ & $(0.023)$ \\
\hline \multirow[t]{2}{*}{ GDP per capita } & $0.020 * * *$ & $0.011^{* *}$ & $0.025^{* * *}$ & $0.018^{* *}$ \\
\hline & $(0.006)$ & $(0.005)$ & $(0.004)$ & $(0.008)$ \\
\hline \multirow[t]{2}{*}{ GDP per capita*EMU } & $0.031^{* *}$ & $0.023^{* *}$ & 0.009 & 0.010 \\
\hline & $(0.014)$ & $(0.010)$ & $(0.005)$ & $(0.015)$ \\
\hline \multirow[t]{2}{*}{ GDP per capita *DKSEUK } & $-0.021^{* * *}$ & -0.001 & $-0.015^{* * *}$ & -0.020 \\
\hline & $(0.006)$ & $(0.008)$ & $(0.005)$ & $(0.013)$ \\
\hline \multirow[t]{2}{*}{ GDP per capita *Non-EMU } & 0.015 & 0.005 & 0.005 & $0.015^{*}$ \\
\hline & $(0.010)$ & $(0.003)$ & $(0.006)$ & $(0.008)$ \\
\hline \multirow[t]{2}{*}{ Fiscal balance } & 0.034 & 0.075 & -0.000 & 0.011 \\
\hline & $(0.049)$ & $(0.102)$ & $(0.040)$ & $(0.050)$ \\
\hline \multirow[t]{2}{*}{ Oil price } & -0.017 & -0.010 & $-0.066^{* * *}$ & $-0.064^{* * *}$ \\
\hline & $(0.017)$ & $(0.020)$ & $(0.015)$ & $(0.015)$ \\
\hline $\mathrm{R}^{2}$ & 0.154 & & 0.263 & \\
\hline $\mathrm{R}^{2}$ within & & 0.244 & & 0.269 \\
\hline $\mathrm{R}^{2}$ between & & 0.453 & & 0.003 \\
\hline Observations & 339 & 339 & 339 & 339 \\
\hline
\end{tabular}

In addition all regressions include a constant. Notes: PW-OLS with PCSE: Prais-Winsten regression with panel-corrected standard errors (panel-level heteroskedastic and correlated across panels, common AR(1) autocorrelation structure, which is estimated from autocorrelation of residuals ( $x$ tpcse command in STATA with correlation(ar1) and rhotype(tscorr) options)); $\mathrm{FE}=$ within estimator using panel robust standard errors (clustering on the panel variable). Panel-corrected standard errors or panel robust standard errors are in parenthesis. ${ }^{*}, * *$ and ${ }^{* * *}$ denote statistical significance at the 10,5 and 1 percent levels. 
Table 12

Regression results for trade balances and per capita incomes in Europe 1984-2011 (including a dummy for the Netherlands).

\begin{tabular}{|c|c|c|c|c|}
\hline \multirow[b]{2}{*}{ Variables: } & \multicolumn{2}{|c|}{$\begin{array}{l}\text { Dependent variable: } \\
\text { Intra balance }\end{array}$} & \multicolumn{2}{|c|}{$\begin{array}{l}\text { Dependent variable: } \\
\text { Extra balance }\end{array}$} \\
\hline & (9) & (10) & (9) & (10) \\
\hline \multirow[t]{2}{*}{ EMU } & 0.002 & 0.003 & -0.006 & -0.006 \\
\hline & $(0.015)$ & $(0.014)$ & $(0.015)$ & $(0.014)$ \\
\hline \multirow[t]{2}{*}{ DKSEUK } & $0.036^{* *}$ & -0.010 & 0.025 & 0.009 \\
\hline & $(0.015)$ & $(0.017)$ & $(0.016)$ & $(0.016)$ \\
\hline \multirow[t]{2}{*}{ Non-EMU } & 0.004 & 0.011 & -0.004 & -0.003 \\
\hline & $(0.014)$ & $(0.013)$ & $(0.020)$ & $(0.019)$ \\
\hline \multirow[t]{2}{*}{ Netherlands } & $0.100^{\star * *}$ & $0.078^{* * *}$ & $-0.101^{* * *}$ & $-0.109^{* * *}$ \\
\hline & $(0.018)$ & $(0.016)$ & $(0.018)$ & $(0.017)$ \\
\hline \multirow[t]{2}{*}{ GDP per capita } & $0.033^{* * *}$ & $0.023^{* * *}$ & $0.022^{* * *}$ & $0.018^{* * *}$ \\
\hline & $(0.006)$ & $(0.006)$ & $(0.006)$ & $(0.007)$ \\
\hline \multirow[t]{2}{*}{ GDP per capita*EMU } & -0.002 & -0.000 & 0.003 & 0.003 \\
\hline & $(0.007)$ & $(0.006)$ & $(0.007)$ & $(0.006)$ \\
\hline \multirow[t]{2}{*}{ GDP per capita*DKSEUK } & $-0.025^{* * *}$ & -0.010 & -0.008 & -0.003 \\
\hline & $(0.007)$ & $(0.008)$ & $(0.007)$ & $(0.007)$ \\
\hline \multirow[t]{2}{*}{ GDP per capita*Non-EMU } & -0.003 & -0.007 & 0.003 & 0.002 \\
\hline & $(0.006)$ & $(0.006)$ & $(0.007)$ & $(0.007)$ \\
\hline \multirow{2}{*}{ Fiscal balance } & -0.018 & -0.002 & $-0.065^{*}$ & $-0.061^{*}$ \\
\hline & $(0.043)$ & $(0.044)$ & $(0.037)$ & $(0.036)$ \\
\hline \multirow[t]{2}{*}{ Oil price } & -0.010 & -0.008 & $-0.043^{* * *}$ & $-0.042^{* * *}$ \\
\hline & $(0.008)$ & $(0.008)$ & $(0.010)$ & $(0.010)$ \\
\hline \multirow[t]{2}{*}{ Dependency ratio (aged) } & $-0.295^{* *}$ & $-0.324^{* *}$ & $-0.274^{* *}$ & $-0.276^{* *}$ \\
\hline & $(0.130)$ & $(0.127)$ & $(0.123)$ & $(0.125)$ \\
\hline \multirow[t]{2}{*}{ Dependency ratio (child) } & $0.533^{* * *}$ & $0.457^{* * *}$ & -0.137 & $-0.170^{*}$ \\
\hline & $(0.101)$ & $(0.095)$ & $(0.090)$ & $(0.089)$ \\
\hline \multirow[t]{2}{*}{ Domestic credit by banks } & $0.010^{*}$ & $0.013^{* *}$ & $-0.012^{* *}$ & $-0.011^{* *}$ \\
\hline & $(0.006)$ & $(0.005)$ & $(0.005)$ & $(0.005)$ \\
\hline \multirow[t]{2}{*}{ Bureaucracy quality } & $0.015^{\star * *}$ & $0.008^{*}$ & $0.009 * *$ & $0.007^{*}$ \\
\hline & $(0.004)$ & $(0.004)$ & $(0.004)$ & $(0.004)$ \\
\hline \multirow[t]{2}{*}{ Real interest rate } & -0.046 & -0.063 & -0.040 & -0.046 \\
\hline & $(0.043)$ & $(0.045)$ & $(0.041)$ & $(0.041)$ \\
\hline \multirow[t]{2}{*}{ Change in RULC } & $-0.092^{* *}$ & $-0.095^{\star *}$ & -0.016 & -0.015 \\
\hline & $(0.041)$ & $(0.041)$ & $(0.036)$ & $(0.035)$ \\
\hline \multirow[t]{2}{*}{ Hofstede's individualism } & & $0.126^{* * *}$ & & $0.049 * * *$ \\
\hline & & $(0.014)$ & & $(0.015)$ \\
\hline $\mathrm{R}^{2}$ & 0.503 & 0.576 & 0.334 & 0.340 \\
\hline Observations & 387 & 387 & 387 & 387 \\
\hline
\end{tabular}

In addition, all regressions include a constant. Notes: Estimation was performed using the Prais-Winsten estimator with panel-corrected standard errors (panel-level heteroskedastic and correlated across panels, common $\mathrm{AR}(1)$ autocorrelation structure, which is estimated from the autocorrelation of residuals ( $x$ tpcse command in STATA with correlation(ar1) and rhotype(tscorr) options)). Panel-corrected standard errors are in parenthesis. ${ }^{*},{ }^{* *}$ and ${ }^{* * *}$ denote statistical significance at the 10,5 and 1 percent levels. 
Table 13

Regression results for trade balances and per capita incomes in Europe 1984-2011 (including change in Target balances, changing the method to calculate autocorrelation parameter, or allowing autocorrelation to be panel-specific).

\begin{tabular}{|c|c|c|c|c|c|c|}
\hline \multirow[b]{2}{*}{ Variables: } & \multicolumn{3}{|c|}{$\begin{array}{l}\text { Dependent variable: } \\
\text { Intra balance }\end{array}$} & \multicolumn{3}{|c|}{$\begin{array}{l}\text { Dependent variable: } \\
\text { Extra balance }\end{array}$} \\
\hline & (11) & (12) & (13) & (11) & $(12)$ & (13) \\
\hline \multirow[t]{2}{*}{$\overline{E M U}$} & 0.001 & 0.000 & -0.005 & -0.004 & -0.005 & 0.001 \\
\hline & $(0.016)$ & $(0.016)$ & $(0.015)$ & $(0.014)$ & $(0.014)$ & $(0.014)$ \\
\hline \multirow[t]{2}{*}{ DKSEUK } & $0.038^{* *}$ & $0.035^{* *}$ & $0.034^{* *}$ & 0.020 & 0.024 & $0.045^{* * *}$ \\
\hline & $(0.015)$ & $(0.016)$ & $(0.014)$ & $(0.015)$ & $(0.018)$ & $(0.016)$ \\
\hline \multirow[t]{2}{*}{ Non-EMU } & 0.002 & 0.001 & 0.004 & -0.005 & -0.001 & 0.001 \\
\hline & $(0.014)$ & $(0.014)$ & $(0.015)$ & $(0.021)$ & $(0.018)$ & $(0.018)$ \\
\hline \multirow[t]{2}{*}{ GDP per capita } & $0.034^{* * *}$ & $0.031^{* * *}$ & $0.038^{* * *}$ & $0.022^{* * *}$ & $0.013^{*}$ & $0.025^{* * *}$ \\
\hline & $(0.006)$ & $(0.006)$ & $(0.007)$ & $(0.006)$ & $(0.007)$ & $(0.006)$ \\
\hline \multirow[t]{2}{*}{ GDP per capita*EMU } & -0.001 & -0.001 & 0.000 & 0.002 & 0.003 & -0.001 \\
\hline & $(0.007)$ & $(0.007)$ & $(0.007)$ & $(0.007)$ & $(0.007)$ & $(0.006)$ \\
\hline \multirow[t]{2}{*}{ GDP per capita*DKSEUK } & $-0.028^{* * *}$ & $-0.027^{* * *}$ & $-0.029^{* * *}$ & -0.004 & -0.003 & $-0.012^{*}$ \\
\hline & $(0.007)$ & $(0.007)$ & $(0.007)$ & $(0.007)$ & $(0.007)$ & $(0.007)$ \\
\hline \multirow[t]{2}{*}{ GDP per capita*Non-EMU } & -0.002 & -0.001 & -0.004 & 0.003 & 0.002 & 0.002 \\
\hline & $(0.006)$ & $(0.006)$ & $(0.006)$ & $(0.008)$ & $(0.007)$ & $(0.007)$ \\
\hline \multirow[t]{2}{*}{ Fiscal balance } & -0.029 & -0.018 & -0.004 & -0.067 & $-0.063^{*}$ & $-0.072^{* *}$ \\
\hline & $(0.042)$ & $(0.042)$ & $(0.037)$ & $(0.041)$ & $(0.038)$ & $(0.037)$ \\
\hline \multirow[t]{2}{*}{ Oil price } & -0.005 & -0.004 & -0.012 & $-0.046^{* * *}$ & $-0.042^{* * *}$ & $-0.045^{* * *}$ \\
\hline & $(0.009)$ & $(0.009)$ & $(0.008)$ & $(0.010)$ & $(0.010)$ & $(0.010)$ \\
\hline \multirow[t]{2}{*}{ Dependency ratio (aged) } & $-0.585^{* * *}$ & $-0.550^{* * *}$ & $-0.389^{* * *}$ & 0.027 & -0.038 & -0.104 \\
\hline & $(0.138)$ & $(0.146)$ & $(0.131)$ & $(0.115)$ & $(0.151)$ & $(0.115)$ \\
\hline \multirow[t]{2}{*}{ Dependency ratio (child) } & $0.432^{* * *}$ & $0.410^{* * *}$ & $0.562^{* * *}$ & -0.039 & -0.120 & -0.048 \\
\hline & $(0.107)$ & $(0.115)$ & $(0.108)$ & $(0.096)$ & $(0.124)$ & $(0.075)$ \\
\hline \multirow[t]{2}{*}{ Domestic credit by banks } & $0.018^{* * *}$ & $0.017^{* * *}$ & $0.015^{* * *}$ & $-0.024^{* * *}$ & $-0.014^{* *}$ & $-0.014^{* *}$ \\
\hline & $(0.006)$ & $(0.006)$ & $(0.006)$ & $(0.006)$ & $(0.006)$ & $(0.006)$ \\
\hline \multirow[t]{2}{*}{ Bureaucracy quality } & $0.019^{* * *}$ & $0.018^{* * *}$ & $0.029^{* * *}$ & 0.006 & 0.002 & 0.004 \\
\hline & $(0.004)$ & $(0.004)$ & $(0.005)$ & $(0.004)$ & $(0.004)$ & $(0.004)$ \\
\hline \multirow[t]{2}{*}{ Real interest rate } & -0.055 & -0.060 & -0.056 & -0.027 & -0.041 & -0.029 \\
\hline & $(0.043)$ & $(0.041)$ & $(0.041)$ & $(0.046)$ & $(0.040)$ & $(0.041)$ \\
\hline \multirow[t]{2}{*}{ Change in RULC } & $-0.078^{* *}$ & $-0.079^{* *}$ & $-0.096^{* *}$ & -0.029 & -0.011 & -0.016 \\
\hline & $(0.039)$ & $(0.037)$ & $(0.039)$ & $(0.044)$ & $(0.034)$ & $(0.036)$ \\
\hline Change in Target balances & $\begin{array}{l}0.015 \\
(0.019)\end{array}$ & & & $\begin{array}{l}-0.006 \\
(0.019)\end{array}$ & & \\
\hline $\mathrm{R}^{2}$ & 0.368 & 0.308 & 0.536 & 0.214 & 0.161 & 0.244 \\
\hline Observations & 387 & 387 & 387 & 387 & 387 & 387 \\
\hline
\end{tabular}

In addition all regressions include a constant. Notes: In models (12)-(13) estimation was performed using Prais-Winsten estimator with panel-corrected standard errors: In model (12) panel-level heteroskedastic and correlated across panels, common AR(1) autocorrelation structure, which is estimated from regression using lags ( $x$ tpcse command in STATA with correlation(ar1) and rhotype(regress) options). In model (13) panel-level heteroskedastic and correlated across panels, panel-specific AR(1) autocorrelation structure, which is estimated from autocorrelation of residuals (xtpcse command in STATA with correlation(psar1) and rhotype(tscorr) options). Panel-corrected standard errors are in parenthesis. ${ }^{*}, * *$ and ${ }^{* * *}$ denote statistical significance at the 10, 5 and 1 percent levels. 
Table 14

Regression results for trade balances and per capita incomes in Europe 1984-2011 (including Uncertainty avoidance index instead of Individualism index)

\begin{tabular}{|c|c|c|}
\hline \multirow[b]{2}{*}{ Variables: } & $\begin{array}{l}\text { Dependent varia- } \\
\text { ble: Intra balance }\end{array}$ & $\begin{array}{l}\text { Dependent varia- } \\
\text { ble: Extra balance }\end{array}$ \\
\hline & (14) & (14) \\
\hline \multirow[t]{2}{*}{ EMU } & -0.005 & -0.006 \\
\hline & $(0.013)$ & $(0.014)$ \\
\hline \multirow[t]{2}{*}{ DKSEUK } & $-0.069^{* * *}$ & -0.031 \\
\hline & $(0.019)$ & $(0.021)$ \\
\hline \multirow[t]{2}{*}{ Non-EMU } & 0.003 & -0.003 \\
\hline & $(0.012)$ & $(0.017)$ \\
\hline \multirow[t]{2}{*}{ GDP per capita } & $0.012^{*}$ & 0.009 \\
\hline & $(0.006)$ & $(0.006)$ \\
\hline \multirow[t]{2}{*}{ GDP per capita*EMU } & 0.002 & 0.003 \\
\hline & $(0.006)$ & $(0.006)$ \\
\hline \multirow[t]{2}{*}{ GDP per capita*DKSEUK } & $-0.013^{*}$ & 0.003 \\
\hline & $(0.007)$ & $(0.007)$ \\
\hline \multirow[t]{2}{*}{ GDP per capita*Non-EMU } & -0.002 & 0.003 \\
\hline & $(0.005)$ & $(0.007)$ \\
\hline \multirow[t]{2}{*}{ Fiscal balance } & -0.012 & $-0.067^{*}$ \\
\hline & $(0.039)$ & $(0.040)$ \\
\hline \multirow[t]{2}{*}{ Oil price } & -0.004 & $-0.043^{* * *}$ \\
\hline & $(0.008)$ & $(0.009)$ \\
\hline \multirow[t]{2}{*}{ Dependency ratio (aged) } & $-0.234^{* *}$ & 0.167 \\
\hline & $(0.116)$ & $(0.137)$ \\
\hline \multirow[t]{2}{*}{ Dependency ratio (child) } & $0.266^{\star * *}$ & -0.146 \\
\hline & $(0.085)$ & $(0.099)$ \\
\hline \multirow[t]{2}{*}{ Domestic credit by banks } & $0.020^{* * *}$ & $-0.019 * * *$ \\
\hline & $(0.006)$ & $(0.006)$ \\
\hline \multirow[t]{2}{*}{ Bureaucracy quality } & $0.008^{* *}$ & -0.000 \\
\hline & $(0.004)$ & $(0.004)$ \\
\hline \multirow[t]{2}{*}{ Real interest rate } & $-0.067^{*}$ & -0.036 \\
\hline & $(0.039)$ & $(0.042)$ \\
\hline \multirow[t]{2}{*}{ Change in RULC } & $-0.074^{* *}$ & -0.015 \\
\hline & $(0.034)$ & $(0.038)$ \\
\hline Hofstede's uncertainty & $-0.170^{* * *}$ & $-0.083^{* * *}$ \\
\hline avoidance & $(0.017)$ & $(0.020)$ \\
\hline $\mathrm{R}^{2}$ & 0.483 & 0.224 \\
\hline Observations & 387 & 387 \\
\hline
\end{tabular}

In addition, all regressions include a constant. Notes: Estimation was performed using the Prais-Winsten estimator with panel-corrected standard errors (panel-level heteroskedastic and correlated across panels, common $\mathrm{AR}(1)$ autocorrelation structure, which is estimated from the autocorrelation of residuals ( $x$ tpcse command in STATA with correlation(ar1) and rhotype(tscorr) options)). Panel-corrected standard errors are in parenthesis. ${ }^{*},{ }^{* *}$ and ${ }^{* * *}$ denote statistical significance at the 10, 5 and 1 percent levels. 